\title{
Federal Statistical Confidentiality and Business Data: Twentieth Century Challenges and Continuing Issues
}

\author{
Margo Anderson* and William Seltzer ${ }^{\dagger}$
}

\begin{abstract}
The roots of the modern concept of statistical confidentiality in the US federal statistical system can be traced directly back to the late nineteenth century efforts of statisticians to ensure full and accurate responses by businesses to statistical inquiries. Officials argued that such confidentiality guarantees were needed to ensure that the providers of enterprise and establishment data could be confident that the statistical agencies could not be forced to share their responses with others, such as regulatory or tax authorities, congressional investigators, prying journalists, and competitors, who might use this information to the detriment of the data provider. Nevertheless, over the years, the principle of statistical confidentiality with respect to information provided by businesses in statistical inquiries has been repeatedly challenged by other executive branch departments, independent regulatory agencies, the courts, Congress, and members of the public, with quite varied results.

The paper uses the published record and archival research to examine the history of challenges to statistical confidentiality, and the responses of the statistical agencies, the federal statistical system as a whole, including the office of the chief statistician in OMB (and its predecessors), executive department and independent non-statistical agencies, the courts, and Congress as well as representatives of the business community. Long-term trends and the implications for maintaining and strengthening the confidentiality protections for establishment- and enterprise-level business data provided to federal agencies for statistical purposes are discussed.
\end{abstract}

Keywords: Confidential Information Protection and Statistical Efficiency Act (CIPSEA), Federal Reports Act, Statistical Policy

\section{Introduction}

Statistical confidentiality is an essential principle of modern demographic and economic datagathering and related statistical research. Today, the term "statistical confidentiality" encompasses in shorthand form a bundle of now widely-recognized activities. These may include legal protections, standards of professional conduct, a set of non-disclosure assurances provided to respondents, or compilation and dissemination practices designed to protect data providers from improper use of their answers.

It wasn't always this way. As we and others have discussed, the practice of statistical confi-

\footnotetext{
*University of Wisconsin, Milwaukee, WI, mailto:margo@uwm.edu

${ }^{\dagger}$ Fordham University, New York, NY, mailto:seltzer@fordham.edu
} 
dentiality has a history. Generations of statisticians and social scientists came to define the principles and practices we take as givens as they built the data production infrastructure of official statistics and social science that evolved in the nineteenth and twentieth centuries.

The roots of the modern concept of federal statistical confidentiality can be traced directly back to the late nineteenth century. In the United States, for example, the efforts of such statisticians as Carroll Wright, first Commissioner of the Department of Labor, ensured full and accurate responses by businesses to statistical inquiries (Goldberg and Moye 1985). Officials in the precursor agency of the Australian Bureau of Statistics recognized that blurring the line between government data collection and regulatory actions would undermine the quality of the data collected; they were willing to destroy individual level schedules in order to protect the confidentiality of responses (Hayter 1892, 19). The leaders of the emerging statistical profession argued that such confidentiality guarantees were needed to ensure that the providers of enterprise and establishment data could be confident that the statistical agencies could not be forced to share original survey responses with others, such as regulatory or tax authorities, congressional investigators, prying journalists, or competitors, who might use this information to the detriment of the data provider. ${ }^{1}$

It is widely recognized in the federal statistics community and by knowledgeable members of the business community that the logic of this position is as true today as when it was first articulated over a century ago. Indeed, in the United States the principle of statistical confidentiality based on analogous reasoning was subsequently extended to information provided by persons beginning with President Taft's proclamation issued in connection with the 1910 decennial census (Anderson and Seltzer 2007). Nevertheless, over the years, the principle of statistical confidentiality with respect to information provided by businesses in statistical inquiries has been repeatedly challenged, and in a number of instances, successfully breached, by other executive branch departments, independent regulatory agencies, the courts, members of Congress, and the public.

We review this history of challenges in the United States. We also examine the responses of the affected statistical agencies and the Office of the Chief Statistician in the Office of Management and Budget (OMB) and its predecessors, as well as those in the executive departments and independent non-statistical agencies, focusing specifically on the period from 1910 to 1965 . Finally, we explore how the courts, Congress, and representatives of the business community responded to those challenges. Standard historical treatments of the federal statistical system, (for example, Eckler 1972; Barabba 1975) generally mention the St. Regis Paper case from the late 1950s and early 1960s, which involved a controversy about the level of protection that could be afforded to file copies of Census Bureau questionnaires maintained by a respondent. Yet a number of other important episodes are apparently unremembered, for reasons we discuss below. The St. Regis case culminated in an adverse decision by the Supreme Court in 1961 and an act of Congress in 1962, effectively overturning that decision and reaffirming the principle of statistical confidentiality.

\footnotetext{
${ }^{1}$ In this paper we do not directly discuss the important issue of the similarities and differences that may characterize issues of the confidentiality of business and personal data. These similarities and differences have important technical, policy, and political implications.
} 


\subsection{Outline of the Paper}

Section 2 reviews the emergence of the concept of statistical confidentiality for micro data collected from business or other economic enterprises in the late nineteenth century, and traces the development of law and administrative practice from the late nineteenth century to 1940. Section 3 traces the legislative history of two statutes passed in 1942 which changed the prevailing legal and administrative practice. Section 1402 of the Second War Powers Act, passed in March 1942, explicitly set aside the confidentiality provisions of the Census Act, and permitted the Commerce Secretary to provide micro data collected in the Commerce Department to agencies across the government if the data were necessary for use "in connection with the conduct of the war." The second law, the Federal Reports Act, passed in December 1942, authorized the Director of the Bureau of the Budget to require one federal agency to provide individual level data to another federal agency, encouraged confidential data sharing across federal agencies, and defined the terms under which such data sharing arrangements could take place.

Section 4 traces the implementation of data sharing under the two laws and a number of specific disclosures of confidential microdata on businesses that took place in the 1940s and 1950s, arising from the efforts of federal law enforcement and regulatory agencies to use Section 1402 of the Second War Powers Act and the data sharing provisions of the Federal Reports Act to circumvent statistical confidentiality. The provisions of Section 1402 of the Second War Powers Act expired when the laws was repealed in 1947. The business data disclosures under Section 1402 seem primarily addressed toward war planning and procurement and appear to have been generally accepted by the business community. The disclosures and denied disclosure requests under the authorization of the Federal Reports Act involved a broader set of issues and caused ongoing controversy between the statistical system and the Justice Department, eventually drawing data providers and the Courts and Congress into the dispute. Section 5 traces the eruption of the controversies about data sharing into public view with the litigation surrounding the anti trust case against the St. Regis Paper Company. That case resulted in a defeat for statistical confidentiality in the Supreme Court in 1961 and Congressional action in 1962 to restore the confidential standard of the Census Act. Section 6 brings the story to the present and discusses the context of these historical controversies on current statistical policy.

\subsection{A Note on Evidence}

This article traces the development of the policy, law, and administrative practice of statistical confidentiality for business data in the U.S. Federal Statistical System. One part of the story is very visible, as the agency leaders promulgated and explained their positions and put in place the practices and rules known today. Much of that story has been told before, though not, we suggest, with the precision and contextual background necessary to fully understand particular developments. We attempt to enhance that history by providing additional context and detail.

Less visible were the challenges, breaches, and controversies that prompted particular innovations, such as legislative or policy changes, or in the case of the legislative removal of the confidentiality protections of the Census Act during World War II, the evidence of the use of microdata for non-statistical purposes. In fact, as discussed below, in a number of instances, the evidence has either been forgotten, deliberately hidden, obfuscated, or otherwise lost to later generations of officials in the statistical system and the general public. 
The research in this article involved archival retrieval of material that was literally buried in the voluminous records of federal agencies or the private papers of public officials. And because that evidence can be scattered across several agencies, housed in archives across the country, and even then be incomplete, we emphasize at the outset that the treatment below is not exhaustive, and a number of relevant archival sources were not examined. As such, the present paper should be considered a report on ongoing research. In addition, it is our goal to bring to a much broader audience the evidence that these controversies existed and had a major effect on the character of the statistical system. We provide additional discussion of the evidentiary base of the analysis at relevant points in the discussion below.

\section{Drawing the Line between Statistical Data and Admin- istrative Data}

National states have always had to collect information on the people, property, and social and economic activities of their societies in order to raise revenue, provide services, police, and defend the state. Early "statists" as they were then called, recognized that the resulting tabular records could be the basis for a new form of knowledge, that such records had value apart from their administrative functions. In the development of statistical data analysis, they pioneered the analysis of patterns of aggregates, and eventually called for governments to collect tabular data "for statistical purposes" only.

Thus, there has been a close and often confusing administrative relationship between state data collection for what we call "statistical purposes", or for "public informational purposes", and for the purposes of surveillance, tax collection, benefits administration, or even military control of people. ${ }^{[2}$ By the early nineteenth century, when "information came of age" (Headrick 2000), individuals and agencies involved in "statistical" analysis developed their own practices, logic, and rules to guarantee the integrity of their new form of knowledge. Officials in statistical agencies recognized that the quality of the data they collected and the credibility of the analyses derived from such data could be compromised if they were seen to be part of an administrative activity of the state. Thus, they strove to separate the statistical agencies of government from those of the administrative agencies involved in the normal regulatory, surveillance, and policing activities of the state. They justified such a divorce on the grounds that without autonomy to collect data and protect the responses from administrative action, they could not provide reliable and trustworthy information and statistical analysis for the proper functioning of the state.

Over the past century, official statistical agencies have developed practices guaranteeing respondent confidentiality (for business, institutional, or individual respondents) both for ethical and practical reasons (such as promoting high response rates and truthful reporting). In current official statistical practice, there is a sharp distinction between data collected for an administrative purpose and data collected for a statistical or research purpose. "Administrative data" fundamentally serve administrative purposes. An agency collects identifiable information on individual respondents in order to secure the administration of taxes, programs, or services. "Statistical data" are anonymous and concerned with distributions, patterns, and

\footnotetext{
2 The literature on the history of state surveillance does not distinguish well between the practices of statistical data collection and administrative data collection. See for example, Dandeker 1990; Lyon 2001; Parenti 2004. For a more discriminating treatment see Higgs 2004.
} 
averages; individual identifiers function only then to guarantee data integrity and perhaps to facilitate statistical analysis, but not to identify individual respondents for administrative actions. Administrative data which are to be analyzed for statistical purposes are stripped of their identifiers and anonymized.

While these principles are well known inside the statistical and data analysis professions, they are not obvious to most government officials charged with enforcing the laws, providing the benefits, and collecting the taxes necessary to run the government. The latter, therefore, have repeatedly sought access to the individual level responses to "statistical data" collected from businesses and other institutional entities for regulatory or enforcement purposes. These claims of access have led to conflicts between the statistical system and the rest of government. In turn, the conflicts have forced officials in the statistical system to articulate the principles of statistical confidentiality and then codify them in administrative practice and policy, law, and standards of professional ethics.

\subsection{Early Challenges}

For most of the nineteenth century, the limited regulatory activities of the United States federal government and the ad hoc nature of most statistical data collections tended to preclude requests to use statistical data for administrative purposes. Indeed, the limited nineteenth century evidence of public concern that statistical data collections would be improperly disclosed suggests that the concern reflected fears that responses to official statistical inquiries would be revealed to the press or private publishers. In 1880, for example, Census Superintendent Francis Amasa Walker went on record to "dispose of the ridiculous slander" that "there is some mysterious connection between the Census Office and the Bradstreet Commercial Agency." Walker assured the public that "no commercial agency or person ...has had or will have access to a single figure in the returns of any manufacturer....Such returns are in their nature confidential, and that confidence will be held inviolable at this office" (New York Times 10/14/1880, p. 8).

Late in the nineteenth century, however, new issues emerged. Congress authorized the federal government to investigate antitrust violations and regulate railroad rates and other forms of interstate commerce. They also created new agencies to undertake this work, including the Interstate Commerce Commission and the Department of Labor. The establishment of these permanent agencies prompted the question of exactly where to draw the line between administrative data and statistical data, and thus, what statistical confidentiality was and how it was to be protected. In particular, the controversy erupted in the new Department of Commerce and Labor in the early years of the twentieth century as Congress placed within the Department ambitious new regulatory agencies, such as the Bureau of Corporations, and older statistical agencies, such as the Bureau of Labor Statistics and the Census Bureau.

Congress had established the Census Bureau as a permanent agency in the Interior Department in 1902. The agency moved to the new Department of Commerce and Labor in 1903. The new Department of Commerce and Labor was an unwieldy amalgam of agencies that included many small federal offices, such as the Coast and Geodetic Survey, the Light-House Board, the Bureau of Standards, the Steamboat Inspection Service, and the Bureau of Fisheries. Many of the offices that moved into the new Department had statistical reporting functions as well as regulatory functions, and for many federal officials and members of Congress, the lines between the two were not well drawn (Anderson 1988). The new Bureau of Corporations, in particular, 
was charged with investigating and reporting upon the operations of corporations engaged in interstate commerce during a period when there was widespread public concern about the excessive power of trusts and large corporations. President Theodore Roosevelt made trust busting one of his major administrative initiatives. Within this environment, officials from the Bureau of Corporations challenged the confidentiality of manufacturing census returns. Officials in the Census Bureau resisted. The position of the statistical agencies in resisting the demands of the regulatory officials was not settled until it reached the level of a cabinet discussion. As Walter Willcox recalled (1914, 452-53) while reviewing the experience of the Census Bureau's first decade as a permanent agency:

And, unless my memory or my information is at fault, when the secretary [of Commerce and Labor] directed that the census schedules of manufacturing establishments should be open to the inspection of officials belonging to another bureau within the same department (the Bureau of Corporations) and the director [of the Census Bureau] refused to obey this order of his superior, because of the pledge of secrecy under which the information had been obtained, the matter was debated in the cabinet and the decision reached that the information on these schedules should not be so used by the government.

In the plans for the 1910 Census, the bureau took steps to codify their understanding of the need for confidentiality of business returns. They proceeded on two fronts. First, the 1909 statute defining the procedures for the 1910 census contained new forceful language assuring business owners and corporations that the information supplied to the bureau would not be accessible to regulators. The new Section 25 (U.S. Census Bureau 1917) stated:

That the information furnished [on an "establishment of productive industry"] shall be used only for the statistical purposes for which it is supplied. No publication shall be made by the Census Office whereby the data furnished by any particular establishment can be identified, nor shall the Director of the Census permit anyone other than the sworn employees of the Census Office to examine the individual reports.

The second innovation built confidentiality guarantees into the promotional materials for the 1910 Census. Most notable was the use of the presidential census proclamation, a practice which has continued to the present (Bohme and Pemberton 1991). Designed both to advertise the census and reassure the public about the uses of the data, President William Howard Taft's proclamation stated:

The census has nothing to do with taxation, with army or jury service...or with the enforcement of any national, State, or local law or ordinance, nor can any person be harmed in any way by furnishing the information required (Quoted in Barabba $1975,27) !$

In other words, the statistical data collected were not to be used for enforcement or taxation purposes. The individual respondent should suffer no direct harm because of an answer on a

\footnotetext{
${ }^{3}$ For the full text, see Records of the Office of Statistical Standards, 1940-1968 (40.7), Entry 147, Box 52, File: Census Proclamations, RG51, NARA. The full text was widely reported in the press. See for example, The Chicago Defender, April 9, 1910, p. 3.
} 
census form. The proclamation forcefully represented the understanding among census officials and other statisticians within government that they were drawing a bright line between their work-providing statistical tabulations and descriptions of society-and the work of other government agencies, whose jobs included collecting taxes, enforcing the law, and administering benefit programs.

The regulatory agencies and some members of Congress, however, were not necessarily reconciled to the position of the statistical agencies. The bright line was challenged during World War I. For example, the non-disclosure language in the 1909 statute applied to economic data, not population data, and Wilson administration officials argued that Taft's proclamation did not have the force of law. Thus, officials used the individual level responses to the 1910 census to investigate and prosecute those who failed to register for the military draft in World War I (Anderson and Seltzer 2007).

In the 1920s, census officials acknowledged that they continued to receive inquiries from operating agencies, and that they sometimes they acceded to requests for individual level information from population census responses, even when those responses would be used to tax businesses. Census Director William Mott Steuart was clearly dissatisfied with the practices, but he admitted to Walter Willcox in 1922 that the bureau was "regularly furnishing to the Internal Revenue Bureau information as to the ages of children, for the enforcement of the tax on establishments employing child labor" (Steuart 1922). In another incident, Herman Byer, Assistant Commissioner of Labor Statistics in the late 1940s, described how the Commissioner of Labor Statistics from 1920 to 1932, Ethelbert Stewart, was said to have responded to congressional pressure in the 1920s to reveal identifiable data. According to Byer, Stewart was asked at a Congressional hearing to reveal the data on individual automobile manufacturers to Congress, and he refused on grounds of confidentiality. When the committee chair threatened Stewart, "Mr. Stewart, our committee will subpoena those records," Stewart responded, "You do, and I'll burn them first" (Duncan and Shelton 1978, 168).

These continuing challenges led to further clarification of policy and law. In 1929, with the support of officials in the Census Bureau, Congress extended the confidentiality protections in the census statute to include unit level responses to census questions for businesses and individuals. In 1930, the Census Bureau requested and received an opinion from the Attorney General that upheld the agency's authority to refuse to release a "list of the names, addresses, occupations, and employment status of women living in Rochester, NY" to the Women's Bureau, Department of Labor (U.S. Census Bureau, 2004, 14).

Thus, from 1880 to 1930, officials in the U.S. Federal Statistical System articulated and publicized the policy of statistical confidentiality, wrote it into statutory law on the census, and found support for their practices and interpretations in a ruling from the Attorney General. Nevertheless, the legal and administrative understanding on the strength of the confidentiality standard continued to be precarious, and officials in the regulatory agencies and some members of Congress continued to ask why it was necessarily to restrict access to individual level statistical responses if there was a compelling public need for the information. 


\section{Challenges of Depression and War}

The economic crisis of the Great Depression and the looming international tensions in Europe once again prompted Congress and government officials to question the necessity for and limits on "statistical confidentiality." Efficiency and modernization were watchwords of statistical policy proposals from 1933 onward, when President Franklin Roosevelt created the Central Statistical Board in order to coordinate federal statistical activities in terms of uniform survey practices, question wording, and classification schemes. In 1939, the functions of the Central Statistical Board were moved into the Bureau of the Budget (BOB). Stuart Rice became the Director of the new Division of Statistical Standards (DSS), and the new office began to wrestle with the issue of confidentiality in the context of broader reform of the federal statistical system ${ }^{[4}$ Rice and other New Deal officials pressed for better data sharing procedures among the agencies of the decentralized statistical system. Should the Bureau of Labor Statistics, for example, be collecting the same industry data as the Census Bureau or the Bureau of Mines? Couldn't one questionnaire be used by several agencies and the responses shared for tabulation and publication? In the late 1930s, Rice proposed legislation to clarify standards for sharing identifiable survey responses across the statistical system. The problem was that when the statistical agencies suggested such sharing, not surprisingly, officials from the enforcement agencies, for example in the antitrust division of the Department of Justice, asked why they too couldn't "share" survey responses. Rice and his colleagues responded by drafting legislation which would define legitimate data sharing for statistical purposes and restrict sharing for purposes of "taxation, regulation, or investigation."

The bills introduced in Congress to provide statutory authority for further coordination and data sharing among statistical agencies opened the confidentiality debate anew, but in the context of other administration initiatives, involved arcane issues of administrative practice that were not high on the legislative agenda. No legislation had passed when war broke out in Europe in September 1939. Almost immediately, the military and civilian agencies charged with national defense proposed gaining access to information in the statistical system for the promotion of "national defense." Wouldn't it be more efficient if the information collected within the statistical agencies could be shared with the defense planning and mobilization agencies, the surveillance authorities in military intelligence, and the FBI, or with the regulatory authorities in the Department of Justice? Rice and the officials in the statistical agencies continued to stress the importance of the separation of statistical data from administrative functions and resisted any modification of confidentiality policy or law.

\subsection{The Second War Powers Act}

In the fall of 1939, the Justice Department went on the offensive and proposed its own modification of statistical confidentiality practices in the Census Bureau. Officials from the FBI proposed an amendment to the Census statute to permit the sharing of individual level survey

\footnotetext{
4 The office exists today in the Office of Management and Budget (OMB) as the Statistical Policy Branch, Office of Information and Regulatory Affairs, headed by Chief Statistician, Katherine Wallman. The Division of Statistical Standards was renamed the Office of Statistical Standards with no change in function in 1952. From the late 1960 s on, it was variously titled the Office of Statistical Policy, the Statistical Policy Division, and the Office of Federal Statistical Policy and Standards. The office was moved to the Commerce Department in the late 1970s and returned to the Office of Management and Budget in the early 1980s. See Duncan and Shelton 1978.
} 
responses with the intelligence agencies (Naval Intelligence, Army Intelligence and the Federal Bureau of Investigation). The Census Bureau and the Commerce Department objected strenuously to the proposed legislation to the Division of Statistical Standards. After several months of wrangling within the administration, and with the 1940 Census looming, President Roosevelt, on the recommendation of Harold D. Smith, Director of the BOB and Stuart Rice's immediate supervisor, agreed that the bill not be introduced in Congress (Anderson and Seltzer 2007).

The controversy about the draft legislation from the Justice Department quieted after the census went into the field and the election season opened, but it did not die. Once Roosevelt had won reelection to an unprecedented third term, officials renewed their agenda to strengthen the nation's defenses. In late 1940 and 1941, the Roosevelt administration created a series of temporary defense agencies designed to ready the United States for war. For example, the Office of Production Management was set up in December 1940 and the Office of Price Administration in April 1941. At the highest levels of the Roosevelt administration, officials still hoped to deploy the individual level information collected by the statistical system for national defense.

Census Director William Lane Austin had mobilized opposition to the Justice Department's draft legislation in late 1939 and early 1940. In early 1941 after the 1940 Presidential election, the administration forced Austin's retirement as Director. His replacement, Mr. J.C. Capt, was a long-time administrative and political functionary, first in the Works Progress Administration (WPA) and then as a confidential assistant to Austin handling political patronage appointments in connection with the 1940 Census. Within days of his confirmation, Capt arranged to have this legislative effort revived. In May 1941, J. C. Capt proposed an amendment to the Census statute which would permit sharing census reports with the defense agencies. The provision became Section 3 of Senate bill 1627 (Congressional Record 1941) and provided:

That notwithstanding any other provision of law, any individual census report or any information contained therein may be used in connection with the national defense program under such rules and regulations as may be prescribed, with the approval of the President, by the Secretary of Commerce. No person shall disclose or make use of any individual census report or any information contained therein contrary to such rules and regulations; and anyone violating this provision shall be guilty of a misdemeanor and upon conviction thereof shall be fined not exceeding $\$ 500$ or be imprisoned not exceeding six months or both.

The bill passed the Senate in August 1941 but languished in a suspicious House Census Committee in the fall of 1941 despite strong efforts from the Census Director and other administration officials to press the legislation (U. S. House of Representatives, 1941).

When war broke out in December and economic mobilization intensified, the U.S. economy was put fully on a war footing and the statistical agencies also mobilized to provide the statistical information needed to prosecute the war. As we have described elsewhere (Anderson and Seltzer 2007), in February 1942, at the suggestion of Census Director Capt, the census confidentiality repeal provision was added to the Second War Powers bill which was passed in late March 1942. The provision (Section 1402 or Title XIV) read:

That notwithstanding any other provision of law, any record, schedule, report, 
or return, or any information or data contained therein, now or hereafter in the possession of the Department of Commerce, or any bureau or division thereof, may be made available by the Secretary of Commerce to any branch or agency of the Government, the head of which shall have made written request therefor for use in connection with the conduct of the war... (U.S. Code Congressional Service 1943).

Section 1402 of the Second War Powers Act thus authorized access to data produced by the Commerce Department "for use in connection with the conduct of the war."

The statutory language specified that "The President shall issue regulations with respect to the making available of any such record, schedule, report, return, information or data, and with respect to the use thereof after the same has been made available." These regulations were provided in the form of a Presidential Executive Order (\# 9157), "Regulations with respect to the Making Available of Records, Schedules, Reports, Returns and Other Information by the Secretary of Commerce, and with respect to the Use Thereof After the Same Have Been Made Available," dated May 9, 1942, about a month and half after the law's enactment.

The Executive Order prescribed the proper form for such requests and specified arrangements for reimbursing the Commerce Department for the costs incurred while providing the requested information. The Executive order also provided that

If the information requested [from the Census Bureau] by the head of the department or agency is of a statistical character, a copy of the request shall be submitted to the Division of Statistical Standards of the Bureau of the Budget [the predecessor of OMB's Office of Statistical Policy] at the time the request is submitted to the Secretary of Commerce

and

the Secretary of Commerce shall inform the Division of Statistical Standards of his action upon each request made, under section 1 of this order, if the information is of a statistical character. (U. S. Code Congressional Service 1943)

\subsection{The Federal Reports Act}

Section 1402 of the Second War Powers Act applied only to statistical data collected in the Commerce Department. Thus, for example, it did not apply to data collected by the Bureau of Labor Statistics or the Immigration and Naturalization Service, nor did it apply to sharing data across agencies for non-defense purposes. It did, however, provide a model. Census Director Capt had used the outbreak of the war to achieve passage of his proposal for the abrogation of confidentiality for war purposes. In the summer of 1942, Stuart Rice and colleagues in the Division of Statistical Standards along with supporters in Congress revived the statistical policy bills from the late 1930s and considered coordination of federal statistical policy and confidentiality more broadly. The Federal Reports Act passed on December 24, 1942, and included standardization of the rules governing the sharing of data, including confidential 
statistical data, among federal agencies (U. S. Code Congressional Service 1943). The relevant language read in part:

Sec. 3. (e) For the purpose of this Act, the Director [that is, the BOB Director] is authorized to require any Federal agency to make available to any other Federal agency any information which it has obtained from any person after the data of enactment of this Act, and all such agencies are directed to cooperate to the fullest practicable extent at all times in making such information available to other such agencies... [with exemptions applying to IRS, and other Treasury agencies...]

Sec. 4. (a) In the event that any information obtained in confidence by a Federal agency is released by that agency to another Federal agency, all the provisions of law (including penalties) which relate to the unlawful disclosure of any such information shall apply to the officers and employees of the agency to which such information is released to the same extent and in the same manner as such provisions apply to the officers and employees of the agency which originally obtained such information; and the officers and employees of the agency to which the information is released shall in addition be subject to the same provisions of law (including penalties) relating to the unlawful disclosure of such information as if the information had been collected directly by such agency.

(b) Information obtained by a Federal agency from any person or persons may, pursuant to this Act, be released to any other Federal agency only if 1 . the information shall be released in the form of statistical totals or summaries; or 2. the information as supplied by persons to a Federal agency shall not, at the time of collection, have been declared by that agency or by any superior authority to be confidential; or 3 . the persons supplying the information shall consent to the release of it to a second agency by the agency to which the information was originally supplied; or 4. the Federal agency to which another Federal agency shall release the information has authority to collect the information itself and such authority is supported by legal provision for criminal penalties against persons failing to supply such information.

Thus, by the end of 1942, legislatively defined mechanisms existed to share confidential data across all agencies of the federal government. Section 1402 was a war measure, specifically addressing the perceived pressing needs for security, procurement, and planning during wartime. The Federal Reports Act was a more general statute designed to improve the efficiency of the federal statistical system overall. Under the new laws, authority for administering such data sharing and monitoring the provisions of Section 1402 of the Second War Powers Act apparently lay with Stuart Rice, as the Director of Statistical Standards in the Bureau of the Budget. Section 1402 was in effect from the spring of 1942 to the end of March 1947, when it was allowed to lapse, along with many other provisions of the Second War Powers Act. The tighter standards of the 1929 Census Act then again became the law governing statistical confidentiality at the Census Bureau. However, after 1947, the Federal Reports Act continued in place. The officials in the statistical system believed that the Federal Reports Act in particular would solve the problems they faced protecting confidentiality while sharing data. They soon found out it did not. 


\section{Implementation: Evidence on Disclosures and Data Sharing}

To date, there has been no systematic analysis of the use and impact of Section 1402 of the Second War Powers Act or the data sharing provisions of the 1942 Federal Reports Act, particularly with respect to data on businesses. In fact, there has been a considerable dispute about the extent of their actual use, for disclosure of either business or demographic data. For example, members of the Japanese American community have often asserted that micro-data from the 1940 Population Census was used to target them (see, for example, Okamura 1981). Other historians also raised questions about the involvement of the Census Bureau in actions directed against the Japanese Americans (see, for example, Daniels 1982). On the other hand, Census Bureau leadership and staff have generally denied that any such disclosures at the micro-level occurred, although from time to time over the years individual census staff have explicitly acknowledged in unpublished papers and correspondence that business data were disclosed (see, for example, Clemence 1986 and Jones 2005).

Similarly, there has been, to our knowledge, no systematic analysis of the relationship between the provisions of Section 1402 and the somewhat similar data sharing provisions of the Federal Reports Act. The statutory language of Section 1402 and corresponding regulations in EO9157 implied that the Commerce Department and the Census Bureau would keep written records of the requests for and transmissions of confidential data. When the requests were of a "statistical character," the Commerce Secretary had an additional reporting requirement to the Division of Statistical Standards in the Bureau of the Budget. Such reporting requirements should have made it possible to audit the uses made of Section 1402 for statistical purposes.

For the data sharing provisions of the Federal Reports Act, the Director of the Bureau of the Budget was explicitly identified as the official authorized to oversee any sharing among agencies. Again, records should have logically been found in the Office of Statistical Standards of the Bureau of the Budget. In fact, the records that were kept and archived seem to be very uneven. Thus, the analysis that follows is not based upon a thorough audit of the archival record in the Bureau of the Budget, the Commerce Department, or the Census Bureau, since we have not found such a record.

We found the evidence of the Section 1402 disclosures discussed below in the records of the Chief Clerk of the Commerce Department. These records are in the General Records of the

\footnotetext{
${ }^{5}$ It is unclear if these reporting requirements represented an effort by Stuart Rice, then the Assistant Director for Statistical Standards in the Bureau of the Budget, to control Census Director Capt's enthusiasm to open the records of the Bureau to the war agencies or simply an effort by Rice to advance his long-time goal of promoting the role of his office in statistical coordination. Unfortunately, since the most egregious violations of statistical confidentiality were not for statistical purposes, it was not necessary to provide information reports to the Office of Statistical Standards in these cases. Moreover, it should be noted that we have not been able so far to locate any reference to the filing of an information report as required under Executive Order 9157 in the archive files for the Bureau of the Budget even for the section 1402 disclosures that were of a purely statistical character. As more fully described below, we did find three letters from Rice among his papers at the Harry Truman Presidential Library to different federal agencies pointing out their failure to notify his office of such requests as required by EO 9157. We were also able to locate a single instance of such a report in the archive files of the Department of Commerce (Taylor, 1944a). This letter pertained to a 1944 request from the Defense Plants Corporation for plant specific production data from the 1939 Biennial Census of Manufacturing for certain specified chemical products.
} 
Department of Commerce, Office of the Secretary, General Correspondence, Record Group 40 (RG40), in the National Archives in College Park, Maryland. Administrative procedure required that interdepartmental communications be routed through the Chief Clerk's office. Section 1402 directed that agencies seeking confidential census information make their requests to the Secretary of Commerce. We do not believe the Chief Clerk's files are complete. The Commerce Department records indicate that originals and file copies were also housed in the Census Bureau records. We have not found any of these materials in the archived records of the Census Bureau (Record Group 29) in the National Archives. We have not, as yet, followed the disclosures of business data discussed below into the records of the receiving agencies, e.g., the War Production Board, though we have followed the paper trail in the case of some disclosures of population data (Seltzer and Anderson 2007a). We make no evidentiary claims as to how the microdata was used or preserved in the receiving agency. Finally, as noted below, once the data transmissions of Section 1402 became routine, it appears that even the Commerce Department reporting channel was dropped, and requesting agencies often contacted Census officials directly.

For the evidence and debates surrounding the non statistical disclosures of business data made under the provisions of the Federal Reports Act, we have relied on the records of the Division of Statistical Standards of the Bureau of the Budget. These records are housed in Record Group 51 (RG51) in the National Archives in College Park, Maryland. We have not found a systematic record of data sharing requests, granted or not, though we are not prepared to state that such records do not exist. They may yet turn up with additional research in RG51. Nor have we systematically followed the controversies discussed below into the records of the operating and regulatory agencies, e.g., the Bureau of Mines (Interior Department), the Federal Trade Commission, or the Department of Justice. Rather, we have relied on the DSS files documenting particular controversies. These voluminous files provide sufficient evidence that the disclosures took place, as well as the efforts by officials in the statistical system to manage the controversies and forestall additional ones.

\subsection{Disclosures of Business Data under Section 1402 of the Second War Powers Act}

Table A contains a summary listing of nine disclosure episodes related to Section 1402 of the Second War Powers Act that we have documented so far in Commerce Department records. These documented disclosures occurred between August 1942 and November 1945. Each episode is based on documentation involving correspondence from the Department of Commerce to a requesting agency forwarding the requested confidential material or conveying a policy decision that the requested confidential information would be released. From other evidence we also know that our list of nine cases over a 40 month period is a lower bound and that Section 1402 disclosures appear to be far more extensive. The upper bound is still very much in doubt, but a hint of the extent of the use of the provision can be seen in Assistant Director for Statistical Standards Director Stuart Rice's correspondence. On August 14, 1942, Rice wrote to officials in the War Production Board, the Tariff Commission, and the Office of Price Administration reminding them that EO 9157 required the requesting agency to copy the Division of Statistical Standards when making requests for confidential information of a statistical character. He listed 26 requests made by the War Production Board between May 9, 1942, the day EO 9157 was signed, and July 30, 1942 (Rice, 1942a); he also listed a July 22 
request from the U.S. Tariff Commission on "oil sulphonating establishments" (Rice, 1942b), and 4 requests made by the Office of Price Administration between May 27 and July 30, 1942 (Rice, 1942c). In other words, there were at least 31 requests in the 96 days between the promulgation of the Executive Order and Rice's letter, a rate of about one every three days. ${ }^{6}$

The requesting agencies were the Department of Agriculture (Food Distribution Agency and the Bureau of Agricultural Economics), the Department of Labor, the Treasury Department, the Tennessee Valley Authority, and four war-time agencies, the War Production Board, the Office of Price Administration, the Defense Plants Corporation, and the Civilian Production Administration. Five of the nine requests for information related to businesses pertained to mailing list information (i.e., company names and addresses), in a few cases clearly designed to assist in the statistical data-gathering operations of the requesting agency. In the remaining cases, specific production data pertaining to individual plants were requested. Many of these disclosures of business-related information appear to involve wartime economic planning or procurement.

The first request for confidential Census Bureau information that we have identified so far was contained in a letter from Donald M. Nelson, Chairman of the War Production Board, to Jesse Jones, Secretary of Commerce, dated August 17, 1942. Nelson, citing Section 1402 of the Second War Powers Act and Executive Order No. 9157, requested that "confidential industrial and economic information in possession of the Bureau of the Census needed by the War Production Board for use in the conduct of the war" be provided to his agency (Nelson, 1942). Nelson indicated that detailed specifications for the "documents and information desired" would be provided by Stacy May, Director of the Statistics Division of the War Production Board; he concluded by stating that "any conditions and restrictions imposed by you upon the use of the documents or information so furnished will be followed." A reply dated August 21, and prepared for Jones' signature, but actually signed by Wayne C. Taylor as Acting Secretary, stated that "this Department is very glad to comply with your request" (Taylor, 1942). However, on August 18, even before the reply to Nelson was signed, Malcolm Kerlin, Administrative Assistant to the Secretary of Commerce, sent a routing slip to Census Director Capt, marking the request "for appropriate action" (Kerlin, 1942).

The next documented request was from the Assistant Secretary of Agriculture to the Secretary of Commerce. It was dated February 1, 1943, and sought mailing lists maintained by the Census Bureau for use by the Agriculture Department's Food Distribution Administration. On February 4, 1943, Wayne C. Taylor, Under Secretary of Commerce replied

The Department of Commerce will be very glad to comply with your request. These lists will be furnished you pursuant to Section 1402 of the Second War Powers Act ... and ... Executive Order 9157 ... with the understanding that the information contained therein will be kept strictly confidential and will not be published in any form. (Taylor, 1943a)

Unlike the letter to Nelson, which had been drafted by the Commerce Department's Assistant Solicitor, E. T. Quigley, the file copy of Taylor's reply to Hill indicates the letter was drafted by Ray Hurley, who later in his career at the Census Bureau headed the Bureau's agriculture statistics program from 1946 to 1968; it carried the distinctive initials of Census Director J.

\footnotetext{
${ }^{6}$ If requests for disclosures continued at this rate for the five years that Section 1402 was in force, approximately 600 disclosure requests would have been made for business data alone.
} 
C. Capt ("JC") and Malcolm Kerlin ("mk"). This file copy also indicates that in accord with normal administrative practice, all the supporting papers sent forward with the letter for signature were returned to the originating Bureau - in the present case, the Census Bureau.

On February 20, 1943, the Executive Director of the Treasury Department's War Savings Staff wrote Secretary Jones requesting mailing lists from the files of the 1939 Census of Business; on February 27, the Under Secretary of Commerce replied indicating (a) that to comply with Executive Order 9157 the request should be resubmitted under the signature of the Secretary of the Treasury and (b) that "to avoid delays, the lists are being prepared and forwarded" as instructed (Taylor, 1943b). Almost three weeks later, the needed letter from Treasury Secretary Morgenthau was forthcoming (Morgenthau, 1943). In addition to specifying the types of businesses in which the War Savings staff was interested (for example, Department Stores, Men's Furnishings, Hats, Clothing Stores, Women's Ready-to-Wear, Shoes, Furniture Stores), the letter stated why the lists were wanted ("mailing War Bond and Stamp posters and other materials"). Two days later, on March 18, Taylor (1943d) replied to Morgenthau writing that as he had indicated in his initial response to Sloan, the materials had already been provided as requested. ${ }^{7}$

Subsequent correspondence indicates the requests for individual-level plant, establishment, or farm data were made by the Defense Plants Corporation (Taylor, 1944a and 1944b), the Tennessee Valley Authority (TVA) (Wallace, 1945a and 1945c), the Department of Agriculture (Wallace, 1945b), the Department of Labor (Wallace, 1945d), and the Civilian Production Authority (Wallace, 1945e) under the provisions of Section 1402 of the Second War Powers Act. Except for the request made by the TVA, all requests for disclosures were granted as requested. In the case of the TVA, a problem arose because a substantial portion of the data were collected privately by a business association, and while the Commerce Department and the Census Bureau were willing to disclose the information obtained by the Census Bureau, they were reluctant to disclose the privately-gathered information. As the Commerce Secretary put it, "the collection problems with some producers were such that the Bureau of the Census might be subject to severe criticism from the Industry, if the suggested information were made available to the Tennessee Valley Authority" (Wallace, 1945c). After informal consultations, the TVA decided to withdraw its request.

Overall, the extant record of disclosures of confidential business data by the Census Bureau under Section 1402 indicates ongoing and wide ranging requests, and that the requested information was provided in a fairly routine manner between 1942 and 1945. Many agencies made requests, and the available correspondence indicates easy communication between the Commerce Department, the Census Bureau, and the requesting agencies. Moreover, even after Section 1402 was allowed to lapse in 1947, several regulatory and investigative agencies continued to be keenly interested in obtaining information on individual firms provided to the Census Bureau under the confidentiality protections of Title 13.

In the short run, agencies strove to find ways to obtain such information directly from the Census Bureau. In one instance, in late 1947, the Federal Munitions Board sought to receive confidential information from the Bureau's Census of Manufactures. After considerable

\footnotetext{
7 This request from the Treasury Department and the Bureau's response was not unprecedented. During World War I, Treasury requested and the Bureau provided similar materials to assist in the promotion of Victory Bonds.
} 
correspondence between the Commerce Department and the Attorney General's office (and extensive consultations involving the Justice Department, the Budget Bureau, the Commerce Department, the Census Bureau, and the Munitions Board), an agreement was reached that disclosures would only be made after the Census Bureau secured affirmative waivers of confidentiality from the individuals and firms who provided the information to the Census Bureau (Foster, 1947; 1948a; 1948b). In another instance, in July 1948, the Census Bureau proposed a similar approach in a letter to the Secretary of Commerce, drafted by W. P. McInerny and A. Ross Eckler of the Census Bureau. In it, they asked for a response to a request by the Internal Revenue Service that it be provided information collected by the Census Bureau from the Zigler Canning Company, which the new Secretary of Commerce, after some hesitation, signed (Sawyer, 1948).

\subsection{Debating Data Sharing under the Federal Reports Act}

Disclosures under Section 1402 had already begun during the summer and fall of 1942 as Congress and the administration debated the legislation that became the Federal Reports Act. Members of the business community were supportive of the legislation, but raised concerns over the data sharing provisions. For example, in November 1942, Bruce A. Fleming, Assistant to the President of the Edwin L. Wiegand Company (makers of electrical heating equipment) wrote to Harold D. Smith, Director of the Bureau of the Budget, expressing his general support for the bill, and offering to approach their Congressmen to lobby for its passage. He also urged that all government questionnaires be authorized for a specific time and carry an expiration date. But Fleming (1942) was also dubious about the confidentiality of statistical reports and commented:

As to the confidential handling of reports, I can assure you there is grave doubt in the minds of many business men as to just how "confidentially" the reports are actually handled by the Bureau receiving them. There is a strong feeling on the part of many business men that financial reports sent to the Treasury Department have a habit of finding their way to the Labor Department. This may or not be true and, if not, any steps you can take to dispel this idea would be a step in the right direction.

Smith (1942) responded to Fleming on November 17, thanking him for his support and suggestions. He also reassured Fleming on "the use of confidential reports." Smith noted that "the strict and rather unimaginative observance" of confidentiality "has been a serious impediment to the elimination of duplication." "That is," he continued, "Agency A has held that it could not disclose certain confidential business information to Agency B, which has then been compelled to collect the same information all over again." He concluded that "one

\footnotetext{
${ }^{8}$ Commerce Secretary Charles Sawyer's hesitation was based on general arguments of government efficiency and his lack of appreciation of the importance of statistical confidentiality (he had been in office only two months at this point). In seeking guidance from the Departmental Solicitor, he asked ( Easton, 1948) "if this is good government practice. In other words... if the prohibition against giving this information applies to the heads of other government departments - such as the Commissioner of Internal Revenue."
} 
advantage" of the proposed law "would be the authority given to the Director of the Budget in such situations." Fleming's concerns of improper use of confidential data were the same ones expressed over the years by the business community and officials in the statistical system. Smith's assurances were designed to encourage support by guaranteeing the protection of the data and highlighting the advantages of data sharing among agencies.

During the war, by and large, the business community was willing to accept assurances like Smith's response to Fleming that the framework defined in Sections 3 and 4 of the Federal Reports Act would protect confidentiality and provide for proper data sharing among federal agencies - regulatory as well as statistical ${ }^{[9}$ The data sharing was in response to war planning. Nevertheless, even before the war ended, the Bureau of the Budget discovered that there were ambiguities in the statutory language. What exactly did Section 4(b) mean when it provided that confidential statistical information collected by one agency could be released to another agency if the second agency "has authority to collect the information itself and such authority is supported by legal provision for criminal penalties against persons failing to supply such information." As the provision was written, the statistical agencies understood this provision to mean that one statistical agency could share survey lists or survey responses if both agencies had the authority to collect the data. That is, the statistical agencies understood the provision to reduce the respondent burden on businesses asked to supply the same information to two statistical agencies, as Smith suggested.

It soon became clear that the regulatory agencies read the language of Section 4(b) of the Federal Reports Act as a broader authorization for data sharing. It also became clear that the statutory language was not explicit in defining the precise channels of authority for deciding which agencies could share data with one another.

In 1945, while the disclosures under the authorization of Section 1402 were still occurring, the Division of Statistical Standards (DSS) recognized the emerging problem. In a series of memoranda involving reconversion plans, DSS officials noted that Justice Department officials had requested "individual-company data" on oil companies from the War Production Board (WPB) and the Bureau of Mines (an agency of the Interior Department that included a well-recognized statistical data-gathering function), and intended to provide the data to the Antitrust Division. The Justice Department, in effect, was asking that the non-statistical data sharing provision of Section 1402 be applied to the data sharing provisions of the Federal Reports Act. If the WPB and the Bureau of Mines acceded to the request, individual-level firm data throughout the entire federal statistical system would be open to examination and use by investigative, regulatory, and law enforcement agencies.

Clem C. Linnenberg of the Division of Statistical Standards wrote a long memorandum to DSS Director, Stuart A. Rice, disentangling the complex questions of the authority of the Division of Statistical Standards, the Bureau of Mines, and the Department of Justice in regards to the transfer of any information from the WPB and Mines to Justice and its Antitrust Division (Linnenberg 1945). Both the WPB and the Bureau of Mines were inclined to resist the Justice Department requests and sought support from the DSS to buttress their reluctance to interpret the reconversion authority of the Justice Department to expand using individual data in the Antitrust Division. One question for DSS was whether the Justice Department

\footnotetext{
${ }^{9}$ For similar concerns in Congress, see the February 1942 debates in the House of Representatives on Section 1402 of the Second War Powers Act, quoted in Anderson and Seltzer 2007.
} 
had the authority under Section 4(b) to access the data. A second was who could make the decision to release or withhold the data from the Justice Department.

Linnenberg recognized that DSS was facing a new situation. He realized that while the Federal Reports Act was designed to facilitate data sharing among federal statistical agencies, its language did not unambiguously define data sharing or protect statistical agencies from demands for data sharing for nonstatistical purposes. "While I think we lack the power," Linnenberg wrote,

even if we had the inclination to require the Bureau of Mines to furnish to the Department of Justice the information desired by it, on the other hand, I see nothing in the Reports Act which empowers the Budget Bureau to direct the Department of Justice to stop pestering the Bureau of Mines or any other agency in this matter, and nothing which empowers the Budget Bureau to direct the Bureau of Mines not to supply the information.

Linnenberg did note that he thought the Division of Statistical Standards might discourage the data transfer by threatening to revoke the approval of the forms necessary to collect such data in the future if the Bureau of Mines complied with the Justice Department requests. But Linnenberg recognized that was a weak reed to lean on. Rather, he proposed a bit of jawboning to try to mediate the situation: 
Certainly the DSS has a broad enough responsibility in the field of Federal Statistics that it would be within its right if it intervened in the Justice-Interior controversy, to try to persuade the Justice Department that the latter's wishes, if complied with, will do serious harm to Bureau of Mines statistical work and will involve bad faith on the part of the Government - both of these factors being very significant from a public policy standpoint. The DSS has a right to intervene in this way, irrespective of whether it can force [emphasis in original] any one to do or not to do anything.

He noted that the only authority the Justice Department might claim to meet the standards for data transfer in Section 4(b) was its subpoena power. That is, the law read that the data was transferable if "the Federal agency to which another Federal agency shall release the information has authority to collect the information itself and such authority is supported by legal provision for criminal penalties against persons failing to supply such information." But he didn't think that such an interpretation accorded with the intent of the statute. "The Department of Justice is not in this position as regards the information here under discussion," Linnenberg noted. "The most it can do is to recommend to a grand jury (which is not a part of the Department, but an arm of the court) to request the court to issue a subpoena duces tecum (an order by fine or imprisonment, to furnish specified information)."

After the war, however, it became clear that the Justice Department did interpret Section 4(b) to include subpoena power to meet the requirements for data sharing. The Federal Trade Commission and the antitrust division of the Justice Department read the provision to mean that they could access confidentially collected statistical information in the context of an investigation of possible trade or antitrust violations. Harking back to their position in 1939 that the FBI should have access to individual level data from the Census Bureau for "national defense," the Justice Department argued that since the attorneys for the FTC or the Antitrust Division had the authority to collect individual level information from companies and to subpoena materials for a grand jury investigation or prosecution, they should have free access to firm level responses to statistical inquiries from the statistical agencies, such as the Census Bureau or the Bureau of Mines. The statistical agencies and the officials in the Office of Statistical Standards in the Bureau of the Budget continued to resist such an interpretation.

Through the late 1940s and early 1950s, the issue simmered. It emerged publicly in 1953 during the review and appraisal of Bureau of the Census programs by the Intensive Review Committee appointed by the Secretary of Commerce. The Intensive Review Committee, informally called the Watkins Committee after its chair, Ralph Watkins, took testimony from other government agencies about their use of census data. The Federal Trade Commission submitted a memorandum in October 1953 complaining strenuously about the confidentiality restrictions on census filings. FTC Chairman Edward F. Howrey (1953) noted that the agency was authorized "1. to prevent unfair competition, restraint of trade, and monopoly, and 2. to obtain and make available to the President, the Congress, and the public factual data concerning economic and business conditions for the guidance and protection of the public and as a basis for remedial legislation."

He continued:

Although the Federal Trade Commission has the statutory authority to obtain from individual corporations the kind of information reported to the Bureau of 
the Census, the latter has refused to make its data available to the commission except on the same basis as they are available to the general public.

The result, he noted, was either duplication of effort as the FTC sought the same information already collected by the Census Bureau, or the inability of the agency "to possess itself of information essential to the discharge of its statutory duties." Howrey detailed what he saw as the obstructionist practices of the Census Bureau and asked the Committee to recommend changes in law and practice in order to facilitate the transfer of information to the FTC.

The Intensive Review Committee (1953) took note of the issue in a section of its report on "Disclosure Rule," and conceded that the Census Bureau might do more to share with the operating agencies:

The Bureau has maintained stringent administrative controls to assure that individual information is not disclosed and has earned the reputation among respondents for respecting the confidentiality of the intimate records submitted to it. This is an asset of great significance and facilitates the taking of the several censuses....

The Committee believes, however, that in certain respects the law has been interpreted with undue rigidity. Specifically, we believe that a reasonable interpretation of the law would not prevent the Bureau from making available to other Federal agencies for statistical purposes lists of names and addresses of business establishments classified by industries under the Standard Industrial Classification.

But the Committee concluded, "A somewhat different problem is presented when another Federal agency having the authority to collect information on a mandatory basis wishes access to census returns to save both government and business concerns the cost of a duplicating survey. Clearly, the Bureau cannot grant that wish." The Committee did recommend that a business could request in writing that a copy of the company's responses be sent to another government agency.

The Watkins Committee Report affirmed the understandings of officials in the statistical system, but neither the FTC nor the Justice Department retreated from their positions. The issue finally came to a head in the late 1950s in a series of confrontations between the statistical agencies and the Justice Department. The first incident pitted the Bureau of Mines and the Office of Statistical Standards (OSS) on one side and the Antitrust Division of the Department of Justice on the other. 10 The second incident was renewed conflict between the Census Bureau and the Justice Department. In all the cases, the antitrust division of the Department of Justice sought access to company filings protected by pledges of statistical confidentiality. The interagency conflicts were complex, and stretched over several years. The outcome of the conflict was an administrative and judicial defeat for statistical confidentiality and the Office of Statistical Standards. In 1958, the Bureau of Mines was forced to permit lawyers from the Justice Department access to company records collected under a pledge of statistical confidentiality. This precedent further emboldened the Justice Department as they pressed their position further and won a test case in the Supreme Court in 1961.

\footnotetext{
10 The Division of Statistical Standards became the Office of Statistical Standards in 1952. See note 4 above.
} 


\subsection{Accessing Confidential Petroleum Data Collected by the Bureau of Mines}

The Suez Oil Crisis was the triggering event that led to the confrontation between the Bureau of Mines and the Justice Department. In 1956, Egypt seized the Suez Canal from an AngloFrench consortium that managed the canal, and the supply of oil was cut to western Europe. In response, the Eisenhower administration facilitated special efforts by the major oil companies to redirect crude oil supply to Europe in the late fall of 1956, what was called "the oil lift program" (Frankel 1959; Engler 1961; Kovaleff 1980). At the same time, the Justice Department was investigating the major oil companies for antitrust violations involving manipulation of supply and price fixing. As far back as the Truman administration, the national security needs of a regular oil supply overrode the efforts to stop unfair trade practices among the major oil companies of the United States. Thus, a conflicting set of reporting procedures existed for the petroleum industry. On the one hand, the Interior Department was charged with collecting routine statistical information through the Bureau of Mines and of overseeing any efforts that might be needed to maintain the free flow of oil to the western world. On the other, the Justice Department was charged with the enforcement of the antitrust laws which prohibited collusion over production, distribution, and sale of oil products.

In January 1957, the price of gasoline at the pump rose sharply, and Congress accused the administration of bungling both the response to the Suez Crisis and the protection of the American consumer. A series of highly publicized Congressional hearings in February 1957 made Interior Department officials look particularly inept (U.S. Senate 1957; Kaufman 1977). Under sharp questioning from Senator Estes Kefauver, Assistant Secretary of the Interior Felix Wormser claimed that although the companies had antitrust immunity while transporting oil during the crisis, that immunity did not extend to coordinating prices to protect the consumer. Kefauver pressed Wormser on the point, asking if he "would do anything about" a 10 cent per gallon gas price rise. Wormser responded that he could do "nothing at all" about such a situation. Kefauver pressed him further, asking about a "fifty cents a gallon" rise. When Wormser again responded he had no authority, Kefauver responded "That is the most outrageous statement I have ever heard" (U.S. Senate 1957, 95; Kaufman 1977, 956).

Seeking to repair the public relations damage, Secretary of the Interior Fred Seaton testified on February 14, 1957, that he understood Congress' concern and that he would cooperate with the Justice Department on the ongoing antitrust investigations of the oil industry. Five days later, on February 19, Attorney General Herbert Brownell took the Secretary up on his offer (Brownell 1957a). Thanking him for his support, Brownell then requested

that the Department of the Interior make available to the agents of the Federal Bureau of Investigation and other authorized representatives of the Department of Justice for inspection and copying all of your Department's petroleum files, including, but not limited to, all files of the Oil and Gas Division, the petroleum and petroleum products files of the Bureau of Mines, and all files of the National Petroleum Council.

Brownell concluded by noting that the grand jury would convene in Alexandria, Virginia on March 4, 1957. 
The Bureau of Mines used a voluntary system of reporting ( Ankeny 1957a). Questionnaires included a statement:

INDIVIDUAL COMPANY DATA-CONFIDENTIAL If permission to disclose is withheld by checking the box marked "NO" in question immediately preceding the signature, the data furnished in this report will be treated in confidence by the Department of the Interior, except that they may be disclosed to defense agencies.

\author{
MAY THE BUREAU OF MINES DISCLOSE YOUR INDIVIDUAL DATA? \\ $\mathrm{YES}_{---} \mathrm{NO}$
}

In early March, Marling Ankeny, Director of the Bureau of Mines, tried to stop the release of confidential responses to Mines inquiries by noting the provisions of the Federal Reports Act and that the Bureau relied heavily on voluntary reporting (Ankeny 1957a). He asked that the Department's response also include a statement on the importance of confidentiality:

The Bureau is concerned over the effects on the respondents of the release of individual company data to the Department of Justice and believes that the letter should indicate the effect that the violation of the promise of confidentiality would have on the Bureau's program....If the respondents were to conclude that the promise not to reveal individual company information does not apply to the Department of Justice, the Bureau's fact-finding program would be placed in serious jeopardy. The precedent established could also disrupt similar voluntary programs of other agencies both inside and outside the government.

The Interior Department supported Ankeny's request, and denied the Justice Department access to the confidential company files of the Bureau of Mines.

But the Justice Department was not satisfied, and in the summer of 1957, reissued its request (Brownell 1957b). Brownell wrote to Seaton suggesting that since "only a small portion of the requested information might require disclosure to the grand jury or the public," Seaton should "authorize the requested release for the purpose of study and analysis by my staff." He again insisted that he needed "access to all of the records in question" and proposed that "after a tentative selection has been completed by my staff, the appropriateness of using that information would be discussed between representatives of our Departments."

Again Director Ankeny strenuously opposed the Justice request and emphatically noted, "Anything that disturbs the pledge of confidentiality made to the respondents at the time of gathering the data would be seriously disruptive of the Bureau's collection program" ( Ankeny 1957b). This time, however, Ankeny's superiors did not support him. This was not surprising, given that Attorney General Brownell was a powerful figure in the Eisenhower administration and his key domestic policy adviser between 1953 and 1957. He had served as chairman of the Republican National Committee and was widely credited with securing Eisenhower the Republican nomination in 1952, later overseeing his successful election campaign that year ("Herbert Brownell Jr., Eisenhower Attorney General, Dies at 92," The New York Times, 5/3/1996, p. A29). 
Reversing its earlier refusal, acting Interior Secretary Hatfield Chilson responded to Brownell on September 5, 1957, and said the Interior Department "will be guided by your opinion" and that he had "instructed the Directors of the Bureau of Mines and of the Office of Oil and Gas...to permit access to the files of their respective agencies" (Chilson 1957).

In the months following, Justice officials gained access to the Mines files according to the parameters expressed in Brownell's August 1957 letter to Seaton. In April 1958, Justice officials pressed further and escalated their requests, asking for "formal release to the Department of Justice of copies of certain individual company returns on Bureau of Mines' standard statistical survey report forms for the years 1956 and 1957" (Ankeny 1958). Ankeny pleaded with officials in the Secretary's office not to accede to the release, noting that the release would set a "Government-wide precedent" and jeopardize the entire statistical system. He pointed out that production was concentrated in the firms covered by their inquiries. If a single large firm refused to cooperate, the resulting statistics would be worthless. Ankeny suggested that the Secretary's office propose that the Justice Department subpoena the information they needed from the firms themselves. He also asked that the other agencies affected, "including the Budget Bureau", be consulted "before a final decision is reached."

While Ankeny continued to try to stall the Justice Department's request, on May 29, 1958, the Alexandria grand jury returned an indictment against 29 oil companies charging them "of having conspired to raise and fix crude oil and gasoline prices after the Suez Canal crisis" (Lewis 1958). The indictments brought increasing pressure on the Bureau of Mines. By the summer of 1958, Ankeny again faced orders from his superiors to give the Justice officials access to the materials.

At this point, the officials in the Office of Statistical Standards, who had been monitoring the controversy for the past year, intervened directly. Raymond Bowman, Assistant Director for Statistical Standards (and Stuart Rice's successor), wrote identical letters to the Secretary of the Interior and the Attorney General on August 27, 1958, asking that representatives from both departments meet with him "before any information....is released" (Bowman 1958). He also raised the issue of the impact of the release on the rest of the statistical system, and asked if there were "other means available of accomplishing that Department's objectives." A series of meetings took place in the fall of 1958, but did not resolve the situation. Officials in the Office of Statistical Standards pointed out to the officials in both the Interior and the Justice Departments that OSS had the authority under the Federal Reports Act to facilitate and adjudicate requests for confidential data between different federal departments. But the OSS officials also recognized that such authority was unenforceable in the absence of willingness on the part of the Interior Secretary and the Attorney General to acknowledge it. Even more worrisome was the lack of a general policy on these conflicts and the danger of establishing a worse precedent by having the Office of Statistical Standards a party to the release.

On November, 28, 1958, officials from the Office of Statistical Standards acknowledged failure. In a particularly blunt memorandum titled "Confidentiality of statistical data - Justice/Interior transfer of data," OSS staff member Peyton Stapp described the situation to Elmer Staats, then Deputy Director, Bureau of the Budget (Stapp 1958a). The memorandum deserves to be read in its entirety to capture both the frustrations of the officials in the statistical system, and the dilemmas of the larger situation:

Accepting the position that it is too late in the negotiations between Justice- 
Antitrust and Interior for the Bureau of the Budget to attempt authoritatively to stop access to Bureau of Mines statistical reports in view of the uncertainty as to our legal authority to prevent it, I will follow the course outlined below if it is agreeable to you.

We will not [emphasis in original] write a letter to the Secretary of Interior expressing disagreement with his decision: to give Justice access to reports which were collected under a pledge of confidentiality because the Grand Jury with which Justice lawyers were working had power to subpoena the records. Such a letter would either have to be backed up with the will to say he should not follow through on his commitment, which I understand we are not prepared to do, or [emphasis in original] with some form of acquiescence in transferring these data under the circumstances now existing. The latter position seems undesirable for us to take - that is I prefer not to have any form of concurrence, even such reluctant acquiescence as this would imply. Instead, I will call Assistant Secretary Hardy ${ }^{\sqrt{11}}$ (I asked him last week to delay carrying through on their commitment to Justice) and say we interpose no further objection, but I will also indicate our feeling and proposed course of action as per next paragraphs.

We have not enunciated a clear cut policy on this matter because I know of no previous case in which confidential data of this sort have been turned over to lawenforcing agencies. ${ }^{12}$ This case violates a time-honored practice. There is in fact a previous provision of law which presumably protected respondents, Section 1905, Title 18. However, the Federal Reports Act does provide for the release of confidential information to another Federal agency if the receiving agency has authority to collect the information itself and such authority is supported by legal provision for criminal penalties against persons failing to supply such information. (We had assumed this power rested in the Budget Bureau and so could be kept under control, that is we could order such release or not order it as the occasion justified, and in my own mind at least such occasions would always involve other statistical uses, or specifically cases where there would be no damage to the individual respondent through use of his individual report.)

It now appears that power to release confidential information rests in the hands of the collector if this condition is met. The practical danger is not only that the individual respondents in this case will not cooperate in statistical requests in the future, but that all respondents to all statistical requests [emphasis in original] will be uncooperative if they cannot depend on the Government's promise that their answers will be held confidential. We should now undertake to issue a policy statement to the effect that no [emphasis in original] collector of statistical data should disclose individual reports to another government agency when they will be used against the respondent for law-enforcement, regulation, taxation, etc., and that any request for access to confidential statistical reports should be cleared with the Bureau of the Budget.

\footnotetext{
11 Assistant Secretary, Mineral Resources, Department of the Interior.

12 Stapp's asserted ignorance of prior disclosures, if true, is an indication of how quickly the disclosures under Section 1402 of the Second War Powers Act seemed to have disappeared from the institutional memory of the Office of Statistical Standards.
} 
Such a procedure, involving issuance of a policy statement de novo, so to speak, avoids acquiescence in any previous violation and also avoids calling any attention to such cases. The fewer people who know about this Interior case the better, for it if were widely known an indeterminate amount of damage to the statistical system woul (sic) be done.

In early December, Stapp requested that the Interior Department stipulate that if the records were to be introduced in evidence at trial, the Justice Department would subpoena them from the company (Stapp 1958b). That is, the conflict between Mines, OSS, and Justice revolved around the meaning of the language in Section 4(b) 4 which provided that confidential statistical information collected by one agency could be released to another agency if the second agency "has authority to collect the information itself and such authority is supported by legal provision for criminal penalties against persons failing to supply such information." Stapp wanted to force this conflict to the fore so it could be resolved by action in OSS. To clarify that he noted, "no collector of statistical data should disclose individual reports to another government agency when they will be used against the respondent for law-enforcement, regulation, taxation, etc., and that any request for access to confidential statistical reports should be cleared with the Bureau of the Budget." Stapp also followed up with Elmer Staats, discussing how to issue a regulation to make the position clear. Staats (1958), however, responded to Stapp's proposal by noting that "my impression on this is that the Bureau [of the Budget] does not have such authority at the present time." He proposed a policy statement instead "outlining the considerations involved and the difficulties presented in the disclosure of individual reports for purposes of law enforcement activity against the company or companies reporting." "In other words," he continued, "such a statement would have as its purpose to dissuade the law enforcement agencies rather than to prevent them from subpoenaing such records from other government agencies. This would leave the door open to them to obtain the same records from the companies concerned."

In short, at the end of 1958, officials in the Office of Statistical Standards had conceded they could not prevent Justice Department officials from using the Federal Reports Act to access individual level records gathered through statistical data collections. Their major hope at the time was to prevent this situation from becoming publicly known, so that they could work toward developing a policy to discourage the Justice Department from using its power to subpoena company level statistical responses. $\frac{13}{13}$

\subsection{Accessing Confidential Company Data at the U.S. Census Bu- reau}

It soon became clear that the Justice Department was not willing to defer to the statistical agen-

\footnotetext{
13 The outcome of Justice Department case against the 29 oil companies was a defeat for the government in February 1960. Against the wishes of the Justice Department, the companies were successful in moving the trial to Tulsa, Oklahoma, in September 1958. The case went to trial on February 1, 1960, and was expected to last several months. On February 12, after the prosecution rested its case, the companies moved for a judgment of acquittal. The judge granted the motion the next day. See New York Times, September 12, 1958, p. 15; September 19, 1958., p. 55; January 31, 1960, p. 72; February 2, 1960, p. 29; February 3, 1960, p. 22; February 4, 1960, p. 20; February 9, 1960, p. 14; February 10, 1960, p. 24; February 13, 1960, p. 11; February 14, 1960, p. 34. We have no evidence that the behind the scenes conflict over the Bureau of Mines data figured in the trial phase of the case.
} 
cies and relinquish what it thought was its authority to access confidential statistical reports for investigatory purposes. While the Mines controversy still brewed, the Justice Department forced the issue in other antitrust cases with the Census Bureau.

Because the Census Bureau micro records were specifically protected by the provisions of Title 13, the Federal Trade Commission and the Justice Department could not gain access to such records through the Federal Reports Act. Ed Goldfield, Assistant Director at the Census Bureau in the 1950s, remembered well in his 1991 oral history interview how these agencies responded to this situation (Goldfield 1991):

In the latter 1950's, the Federal Trade Commission was engaging in what some people might called a "fishing expedition" or a "witch hunt." What they were doing was looking for evidence of anti-trust procedures in certain industries. Some of their emissaries came to me and said: "We have a list of companies in this industry that we would like to check out, and we would like to see the records that you have from the census of manufactures and whatever else you have from these companies." I said: "No, you cannot see them," as was the case in all the face-offs I had with the Federal Bureau of Investigation, the Secret Service, and others. They were surprised and appalled, and could not believe that I was telling them that the Census Bureau was not going to help them do the work that was important to the welfare of the country. I was insistent about it, however, and I told them (as I had told the representatives of other such agencies): "Go back and check with your legal authority, and I think you will find that I am right." They did so, and they found that the census records, particularly from the census of manufactures, which they were especially interested in, could not be given to them by the Census Bureau, even for a worthy cause. I said to them: "You are a regulatory agency; you are armed with legislation that gives you the authority to compel any companies, firms, or establishments that you are interested in to give you information that is appropriate to your regulatory responsibility. You can take a blank census form and copy it over and put your name on it, and say: 'This is what we are demanding of you,' and send it to whatever company you want and get the same information."

They said: "No, that would not be satisfactory. If we get a form that the company gave to the Census Bureau, we would believe that it would have been honestly filled out under the guarantee of confidentiality that the Census gave. The [company officials] would have responded to the census because they felt that no harm would result, and that they were interested in helping to produce good statistics for their industry. But if the Federal Trade Commission asked for the same answers for the same questions in our own name, this is like asking them to testify against themselves. We will not get results that are as credible [as the census]. We want to be able to walk into court and wave a copy of a census questionnaire and say: 'Here is what the company honestly reported against itself, and it shows it is unduly dominant in this industry or whatever."' My response to the Federal Trade Commission was not satisfactory to it.

Then they learned that when the Census Bureau took economic censuses, the material suggested to respondents that they keep a copy of the questionnaire that 
they sent back to the Bureau. More precisely, firms received an extra blank questionnaire copy for this purpose which said: "If we have any questions about your return, you will have a copy to look at while we are asking you these questions; or, when you get the next questionnaire for the next census or survey, you can look at how you filled out the previous one." So, a lot of the companies kept copies as a general practice. The Federal Trade Commission got to thinking: "Well, if we cannot get the questionnaires from the Census Bureau, we will subpoena the copies from the company." They did so in a number of cases, some of them were brought to court because the companies challenged the subpoenas on the grounds that their census returns were supposed to be confidential. One of the cases that went to the courts was one involving Beatrice Foods, another involved the Borden Company, and another involved the St. Regis Paper Company. These cases first came under the jurisdiction of U.S. district courts, and then to U.S. appellate courts in various parts of the United States which handed down conflicting conclusions. In a couple of the cases, the Federal Trade Commission's position was upheld, and in other cases, the company was upheld. That is, the courts said, in effect (I think I am quoting one of the decisions), "The United States has given its word and it should not be overturned...."

In the Beatrice Foods case, the appeals court sided with the company and upheld the confidentiality of the file copy of the company's census files (Federal Trade Commission v. Dilger 1960). In the St. Regis case, a conflicting appeals court decision sided with the FTC, and the issue then came before the Supreme Court for resolution.

\section{St. Regis Paper Case}

In the second half of the 1950s, the Federal Trade Commission was investigating possible antitrust violations at the St. Regis Paper Company. The Commission opened an inquiry in September 1956, and made numerous requests for documents from the company, including file copies of the company's census forms. The FTC met stiff resistance from the company. In July 1959, the Commission declared St. Regis in default on its obligations to report, and initiated proceedings to fine the company $\$ 100$ a day for noncompliance. St. Regis complied with all requests by April 1960, except for the requests for the file copies of the company's 1958 census reports. St. Regis went to court to appeal the fines and to protect the file copies of its census forms. St. Regis relied on the language of Title 13, Section 9 (a) which required that the Census Bureau not:

1. use the information furnished under the provisions of this title for any purpose other than the statistical purposes for which it is supplied; or

2. make any publication whereby the data furnished by any particular establishment or individual under this title can be identified; or

3. permit anyone other than the sworn officers and employees of the Department or bureau or agency thereof to examine the individual reports.

The Second Circuit Court of Appeals ruled in December 1960 that the file copies held by the company were not protected by the confidentiality protections of Title 13, Section 9 (a), and ordered the company to turn over the files to the Federal Trade Commission. Since the Seventh 
Circuit Court of Appeals had ruled that the file copies were confidential, St. Regis appealed the decision to the Supreme Court in early 1961, and the Supreme Court accepted the case to clarify the law.

The St. Regis case brought into public view the behind the scenes bureaucratic struggle between the regulatory agencies and the statistical agencies that had been brewing since the passage of the Federal Reports Act. On the surface, the case appeared to be a minor dispute about arcane issues of the forms of evidence and the powers of the Federal Trade Commission to regulate unfair trade practices. But for the statistical agencies, and for those insiders aware of the context of the almost 20 year struggle to define the boundaries of statistical confidentiality, the case loomed very large indeed. For these officials, the St. Regis case was all the more distressing, since the FTC was challenging the oldest and strongest confidentiality provisions in American law, namely the guarantees of Title 13. The Bureau of Mines had relied on its administrative practice to resist the Justice Department. If the FTC prevailed in its interpretation of Title 13, then statistical data collections could indeed be jeopardized across the government.

The different readings of the issues involved can perhaps be seen by comparing the internal court memoranda on the case at the Supreme Court with the discussions inside the statistical agencies and the Office of Statistical Standards. The statistical agencies were extraordinarily troubled by the prospect of a Supreme Court decision voiding the confidentiality protections of Title 13. In June 1961, for example, while the St. Regis case was pending, the Director of the Bureau of the Census, Richard Scammon, wrote to Lee Lovinger, Assistant Attorney General, pleading with him to take action to stop further efforts by the antitrust division to subpoena confidential Census of Business reports (Scammon 1961):

Andrew Kilcarr [of the Justice Department] has been kind enough to informally advise us of the intention of the Anti-Trust Division to subpoena a respondent's file copy of a confidential Census of Business report in connection with an action involving a company in the banana business....

This raises again, Lee, this whole problem of the confidentiality of census returns and I'd like to re-emphasize the seriousness with which we here view these legal actions....

It is a matter of fact that the Beatrice and St. Regis cases have caused widespread suspicion of our Census Bureau representations with respect to confidentiality representations which we make to companies as part of the inducement to file reports promptly, often voluntarily, and on a uniform statistical basis without regard to the varieties of formal records maintained by individual businesses. We are now lacking reports from some of our largest companies in a few of our basic series, and there is evidence of increased reluctance to supply data voluntarily.

Scammon continued by explaining that the bureau requires "reports before final audited records are available" and "prompt returns without having them pass through the hands of legal counsel for consideration of their implications of other laws". Scammon emphatically stated that "the attempt to break into the confidential relationship between the respondent and the central statistical agency will erode the basic sources of information" and "will impair our democratic processes by limiting the variety and accuracy of the statistical information needed if the 
decisions made by the people and the Government are to be based on an adequate knowledge of the facts." Noting that he felt that "great harm can come to the country" if the antitrust division continued to subpoena statistical reports, he offered to meet "at any time" and find an "acceptable conclusion".

The conflict between the Justice Department and the statistical agencies also spilled out in the briefs to the Supreme Court in the St. Regis case. The Commerce Department submitted a brief opposing the FTC action, and the Bureau of the Budget also opposed the FTC attempt to use its subpoena power to gain access to the company copies of the census forms.

Still, the Justice Department did not relent, and the St. Regis case moved to decision before the Supreme Court in the fall of 1961. Within the Supreme Court, many of the Justices had a quite different perspective from the statistical agencies on the issues involved. For a number of the Justices, the principle of statistical confidentiality seemed to be a side issue and the recalcitrance of the St. Regis Paper Company was the central issue of the case. Justice Tom C. Clark was the author of the majority opinion in the case. It is clear from his court files that the members of the court did not see the statistical confidentiality issues as terribly important, and that the case was overall a relatively minor one. In the late 1930s and 1940s, Clark had served in the Antitrust Division of the Justice Department, headed the War Frauds Unit of the Justice Department during World War II, and served as Attorney General in the Truman administration. This experience gave him major experience in the complex issues of antitrust, and he showed little sympathy for what he considered as the company's stalling. In November 1961, Clark wrote a memorandum to the court's conference proposing that the court affirm the court of appeals decision (Clark 1961):

A careful study of this record convinces me that St. Regis, through its attorney Horace Lamb, for three years openly defied the Orders of the Federal Trade Commission, was contemptuous of its officers and did everything possible to obstruct the investigation.

In his eight page memorandum, Clark devoted seven pages to detailing the recalcitrance of St. Regis and untangling the complex questions of whether the company should be fined for non compliance. Only in his last page of discussion, did he turn to the question of the confidentiality of the census reports:

There can be no doubt that literally construed the provisions of Section 9 (a) of the Census Act do not render confidential the copies of the reports made by corporations and retained in their files....The suppression of otherwise competent evidence is serious business and statutes doing so are strictly construed. To say that the language here makes the copies confidential would open up a field not heretofore considered restricted.

He acknowledged that the briefs of the Solicitor General had noted the opposition of the Bureau of the Budget and the Census Bureau to this interpretation, and he conceded that such a decision might not be prudent public policy. But, he concluded, the court should not so rule. "After all," he noted, "Congress can amend the statute."

The next day, Chief Justice Earl Warren responded to Clark ( Warren 1961). "I am persuaded 
by your memorandum in the above case that the penalties for failure to answer the questions should be sustained," Warren wrote. "I am still somewhat up in the air on the copies of the census reports," he continued, and he reported that by his count, the court was split on the issue. But he continued, "I think this is not so terribly important however, because as I understand it the information is available to the Commission, if not through these reports, through spade work. Copies are not required to be kept, and I suppose anyone who wanted to thwart the Commission could just destroy the copies, and if they wanted to produce them they would do so without controversy." In the next several days, the Justices cast their votes on the case, and it became clear that Clark's opinion carried the majority. In December, the court ruled six to three that the file copies of census forms were not confidential. The court ordered St. Regis Paper turn over the file copies to the FTC.

Clark prepared the opinion delivered in December. He based his majority opinion on a strict reading of the Census statute: "Congress did not prohibit the use of the reports per se but merely restricted their use while in the hands of those persons receiving them, i.e., government officials. Indeed, where Congress has intended like reports not to be subject to compulsory process, it has said so" (St. Regis Paper Company vs the United States, 1961; quoted in Rubin, 1962, 28). He again noted that Congress could modify the statute if appropriate.

In a dissenting opinion, Mr. Justice Black supported the statistical agencies and criticized Clark for missing the point. He argued that the majority opinion made a mockery of the agency's pledge printed on its forms that any information given would not be used "for purposes of taxation, investigation, or regulation." Black noted that the

Census Bureau and the President promised that the Census Bureau would keep Census reports particularly confidential. . . Quite plainly, the promised protection was against governmental "taxation, investigation, or regulation" generally, and to protect the integrity of that promise, it is, of course, necessary that all of the particular arms of Government which are engaged in those activities be bound by the Government's pledges. Our Government should not, by picayunish haggling over the scope of its promise, permit one of its arms to do that which, by any fair construction, the government has given its word that no arm will do (quoted in Rubin 1962, 28).

Once the decision was announced, the Census Bureau and other officials of the federal statistical system mobilized to counter its impact, since they knew that the outcome of the case would have an extraordinarily damaging impact on compliance with its censuses and surveys. In early 1962, the issue moved to Congress, as a number of bills were introduced to clarify the meaning of the confidentiality pledge in Title 13. The debate was extraordinarily broad and to our knowledge was the first time in the twentieth century that Congress undertook a full examination of the purposes of and potential limitations on statistical confidentiality. In the summer of 1962, the House Committee on Post Office and Civil Service conducted far reaching hearings and heard from dozens of witnesses on all sides (U.S. House of Representatives, 1962). Once again, positions aired both supporting and opposing strong standards of statistical confidentiality. Defending the standard as it had developed over the past 50 to 75 years, Census Bureau Director Richard Scammon testified:

Once you start saying that material is not confidential, that material may be used to your disadvantage, that this material may be used to your disinterest, then you 
are going to get just as dubious a set of reports as the imagination of man can devise and I would suggest that this imagination is a pretty far reaching thing (U.S. House of Representatives 1962, 23; also quoted in Rubin 1962, 28).

On the other side of the argument were the defenders of a government that could efficiently investigate and prosecute unlawful business practices. Echoing the logic of coordination underlying the Federal Reports Act, Emmanuel Celler (D-NY), Chair of the House Judiciary Committee, came before the House Post Office and Civil Service Committee to testify in favor of the Supreme Court majority view. Celler had also been a member of the House Judiciary Committee in the 77th Congress, and participated in the debates about Title XIV of the Second War Powers Act (U.S. House of Representatives 1962, 34, 38, 39). He thought that the St. Regis decision should be taken further:

As a general rule, information in the files of one agency should be available to other agencies of the executive branch in the enforcement of the laws. The administration of justice should not be reduced to the level of blind man's buff, played by different departments of the same government.

If the Bureau of the Census has in its files information relevant to a violation of the antitrust laws, it seems to me as a general proposition that such information should be available to the Department of Justice and the Federal Trade Commission the agencies charged with antitrust enforcement.

It would be more appropriate, therefore, to repeal the secrecy presently accorded the original census returns in the possession of the Bureau of the Census than to extend the shroud of secrecy to file copies of census returns retained by reporting companies.

Celler derided the statistical agencies' claims for the need for confidentiality. He charged that the claims were smokescreens for bureaucratic self protection: "These bills are symptomatic of a dangerous climate of secrecy among Government agencies. Among the worst offenders, I am told, are the Bureau of the Census, the Bureau of Mines and the Bureau of the Budget." Celler did not mention the controversy surrounding the Bureau of Mines petroleum data, but clearly the Bureau of Mines and the Bureau of the Budget had suffered in reputation with this powerful House committee chairman. Celler raised an opposing argument defending his position that statistical data should not be covered with a pledge of confidentiality: "The right of the people to know what their Government knows is indispensable to that informed public opinion which alone can make our democracy work." "These bills promote an abuse of secrecy," he continued:

Secrecy so abused in this instance is a threat to our free enterprise system-a system whose freedom depends upon the ability of our Government to enforce the antitrust laws.

Advocates for both sides of the debate found support in the basic principles of democracy, open government, and the integrity of the free enterprise system. In commenting on the St. Regis case and the Congressional response, Corcoran $(1963,39)$ observed that 


\begin{abstract}
Although understanding the motivation behind Representative Celler's remarks, the Subcommittee could not agree that the confidence accorded census information should be repealed . . . The high degree of confidence now held by the general public for the Census has been earned over the years - few other Government agencies have such a high repute in the business community. The statements presented at the Subcommittee hearings by trade associations, businessmen, economists, statisticians, and many others attest to this fact.
\end{abstract}

\title{
5.1 Reestablishing the Confidentiality Standard
}

In the late summer and early fall of 1962, Congress accepted the arguments of the statistical agencies and the industry representatives who testified in July. They rejected the Justice Department and Celler's position and amended Title 13 to provide a confidentiality guarantee for the file copies retained by companies filing census reports (Title 13, U.S.C, Section 9; Public Law 87-813). The new language read:

No department, bureau, agency, officer, or employee of the Government, except the Secretary in carrying out the purposes of this title, shall require, for any reason, copies of census reports which have been retained by any such establishment or individual. Copies of census reports which have been so retained shall be immune from legal process, and shall not, without the consent of the individual or establishment concerned, be admitted as evidence or used for any purpose in any action, suit, or other judicial or administrative proceeding.

President Kennedy signed the bill on October 15. The Cuban missile crisis began the next day, and census confidentiality was swept from the attention of Congress and the public.

\section{Since 1965}

We conclude with a brief review of what has changed and what has remained the same over the past 40 years with respect to the confidentiality of business data. In so doing, we hope to highlight some of the implications of our story for current statistical practice and identify continuing issues about statistical confidentiality since the St. Regis decision.

The 1962 amendment to Title 13 ended the period of intense struggle between the Justice Department and the Census Bureau over the meaning of the Federal Reports Act and the reach of the regulatory agencies' access to confidential statistical information on businesses gathered by the Bureau. Moreover, the arguments advanced by those who supported Congressional action to amend Title 13 to prevent the use of firm-level business data collected by the Census Bureau to aid in the investigation, prosecution, or regulation of the involved firms would seem to apply with equal validity to such information collected by other federal statistical agencies and programs. Since Congress accepted this position and amended Title 13, some presumption of Congressional intent in these matters could be reasonably inferred.

Nevertheless, there is evidence that the Justice Department and the regulatory agencies still 
maintain their position, that statistical confidentiality laws and respondent assurances notwithstanding, the federal statistical system is an appropriate source of evidence about individual firms. Furthermore, as was the case of Herbert Brownell under President Eisenhower and Robert Kennedy under President Kennedy, Attorneys General have been politically wellconnected and powerful figures in many subsequent administrations.

In the late 1980s and early 1990s, for example, amidst price rises occasioned by the December 1989 Heating Oil Crisis and the Persian Gulf Crisis, Department of Justice officials opened investigations of alleged price-fixing by oil companies. The Justice Department asked the Energy Information Agency (EIA), which collects statistical data on the oil industry, to provide individual level firm data to the Justice Department for the investigation. The EIA refused and the Justice Department initially closed its investigation without gaining access to the data (Duncan, et al. 1993; U.S. General Accounting Office 1993, 130). The EIA believed that as a statistical agency, any "proprietary data" it collected was covered by a shield of statistical confidentiality and should not be used for law enforcement purposes. However, the Justice Department disagreed, reopened the matter, and in March 1991 issued a decision, which still stood as policy on the EIA website until 2005, that the EIA was required by statute to release any data it collects, including company-specific proprietary information, to any federal agency requesting the data for official use, including to the Justice Department for law enforcement purposes. Whether there are further examples of efforts - successful or unsuccessful - to use the federal statistical system to gather evidence against individual responding firms certainly merits further research and perhaps Congressional examination, particularly given the 1962 action by Congress to strengthen Title 13 .

There has been, in fact, relatively little public discussion about the confidentiality of firm level data in the federal statistical system in the years after 1962. Part of this may have been due to the organizational changes affecting the federal statistical system over the past four decades. The Bureau of Mines, for example, was abolished in 1996, and its functions dispersed to the Geological Survey (Interior Department) and the Departments of Energy and Health and Human Services. The Office of Statistical Standards has undergone several periods of institutional migration and restructuring since the 1960s. It now resides in the Office of Management and Budget (successor to the Bureau of the Budget) as it did from the 1940s to the 1960s.

For whatever reason, most recent discussions about statistical confidentiality have focused on threats and protections related to data on persons. For example, in the late 1960s, Congressman Jackson Betts (R-OH) mounted a challenge, ultimately unsuccessful, to the mandatory nature of the questions in the 1970 census. Similarly, proposals to begin the creation of what was called at the time a "National Data Bank" foundered on fears of "Big Brother" and an overreaching national government (Eckler 1972; Eckler; President's Commission on Federal Statistics 1971). And in the early 1970s, privacy became a major public issue for the federal government as Congress passed the Privacy Act of 1974 to protect individual information from government intrusion. The impact of these and other developments seemed to strengthen the priority being accorded to confidentiality protections for personal data in the federal statistical system at least through September 11, 2001.

As described elsewhere (Seltzer and Anderson 2002; 2007b), the crisis of 9/11 prompted Congress to weaken statistical confidentiality related to personal data collected by the National Center for Education Statistics in provisions of the Patriot Act. In 2002, in seemingly 
contradictory legislative efforts, Congress passed a recodification of that weakening in the Education Research Reform Act of 2002 (PL 107-279 2002), but also adopted major new legislation on data sharing and statistical confidentiality in the Confidential Information Protection and Statistical Efficiency Act of 2002 (CIPSEA) (PL107- 347, 2002). The Office of Management and Budget promulgated Implementation Guidance for protecting and sharing statistical data under CIPSEA on June 15, 2007 (Office of Management and Budget 2007).

With CIPSEA, Congress at long last enacted general legislation offering statistical confidentiality protections to all federal statistical agencies. Because of the potential importance of this new law for confidentiality protections that can be accorded business data collected by agencies other than the Census Bureau, it is useful to compare the relevant language in CIPSEA with that of the older provisions of the Federal Reports Act 14

Several points are noteworthy. CIPSEA includes a formal definition of "statistical purposes" of data and distinguishes these from "nonstatistical purposes." The law "findings" include statements of the importance of assuring public trust in gathering statistical data, and that statistical data collection "serves both the interests of the public and the needs of society." The language of the rules governing disclosure is clearer than that of the Federal Reports Act and does not contain the kinds of exceptions that plagued the Office of Statistical Standards in the 1940s and 1950s:

\footnotetext{
${ }^{14}$ One feature of CIPSEA is that it explicitly does not weaken the confidentiality protections provided by other legislation, such as Title 13.
} 
...Data or information acquired by an agency under a pledge of confidentiality for exclusively statistical purposes shall not be disclosed by an agency in identifiable form, for any use other than an exclusively statistical purpose, except with the informed consent of the respondent.

Nevertheless, we are not completely convinced that officials charged with protecting statistical confidentiality would be able to withstand a sustained assault once again if sufficiently important public purposes were raised to challenge it. We are concerned in particular that the lessons of the 1940s, 1950s, and early 1960s have not been passed to the next generation. The power of the Statistical Policy Office to resist improper data requests inside the administration and away from public view is still limited by its place in the overall policy environment of the Office of Management and Budget and larger administration priorities. Possibly further hampering its ability to resist threats to statistical confidentiality, particularly if supported by an Attorney General or another politically powerful administration figure, is the comparatively low position of the Statistical Policy Office in the bureaucratic structure of the OMB.

In both Democratic and Republican administrations, executive branch officials and the courts have, when faced with competing public needs, been disinterested in supporting, if not openly hostile to, the protection of statistical confidentiality, recalling Justice Clark's understanding that "Ours is the duty to avoid a construction that would suppress otherwise competent evidence unless the statute, strictly construed, requires such a result." By contrast, once the issues have been joined publicly, with some notable exceptions like that of Congressman Emanuel Celler, the record in Congress has been far more supportive.

Thus, in the years ahead we expect quiet administrative debate about the meaning of the CIPSEA protections in particular contexts, and possible court challenges. A preliminary indication of how this debate is proceeding may be gleaned from the fact that it has taken over four years for OMB to issue regulations relating to the implementation of CIPSEA (Cf Wallman 2003).

Accordingly, we propose both additional transparency by those in the federal statistical system about the confidentiality issues they confront and further analysis of the historical record pertaining to these issues by those in and outside of the federal statistical system. Both approaches should help us all to better understand the current challenges to statistical confidentiality and the larger history of institutional pressures on the federal statistical system in this area. By way of analogy, the military, in planning for future challenges, makes use of both current intelligence and first-rate historical research of what went right and what went wrong in the "last war."

The institutional history traced in this paper does not appear to be common knowledge among subsequent statistical policy makers. In 1959, Peyton Stapp of the Office Statistical Standards warned that the long controversy between the Bureau of Mines and the Department of Justice would damage the statistical system if it became public knowledge. Unfortunately, he and later officials did not consider the problems for future statistical administrators and others concerned with the health of the federal statistical system if a careful analysis of the problems he faced were not transmitted to the next generation. (Indeed, as we have noted, Stapp himself appears to have been blind-sided by some of his predecessors about disclosures under the Second War Powers Act.) 
One perhaps can forgive William Lane Austin for his public statement, patently an exaggeration in the heat of challenges to the income question in the 1940 census, when he assured the public that "the Census Bureau throughout its 150 years has never violated the law requiring secrecy." 15 But one wishes that the officials in the Office of Statistical Standards from the 1940s, 1950s, and 1960s had transmitted their institutional knowledge to the next generation of officials. Joseph Duncan was Deputy Associate Director for Statistical Policy, Executive Office of the President, Office of Management and Budget in the 1970s. In a paper delivered at the Social Statistics luncheon at the 135th annual meeting of the American Statistical Association in Atlanta, GA, on August 25, 1975, he spoke on "Confidentiality and the Future of the U.S. Statistical System". Duncan proposed several propositions to his audience (Duncan 1976, 54). He assured them that "The protection of the confidentiality of individual responses to statistical inquiries has long been a paramount consideration in the statistical system...." and that the "statistician has long asserted that the protection of data confidentiality is essential to assure the accuracy of statistical programs..." He went on to assure his audience that "The record of statisticians is clear. I do not know of one instance in which there has been a breach of confidentiality pledges by statisticians in the Federal Government...." We strongly support Duncan's first two propositions but we also suggest that the third needs revision.

The standard of statistical confidentiality is extraordinarily important for the integrity of the statistical system and the data needs of society. We also suggest that the standard will continue to be challenged and its institutional defenders portrayed as hidebound bureaucrats creating an unnecessary impediment to proper and efficient government action. The officials so charged find it difficult to defend themselves, without mobilizing their natural allies among the data providers and users. In the case of business data, an important and powerful set of respondents exists. It is thus necessary and appropriate for officials and other stakeholders in the larger public to be aware of and draw on this resource in supporting the principle of statistical confidentiality throughout the federal statistical system.

\section{Archival Resources}

\section{National Archives:}

Record Group 29 (RG29), Records of the Bureau of the Census (Washington, D.C.). Entry 202, Joseph Hill Papers, Entry 372L Files of C. Louis Kincannon, Deputy Director (1981-1992).

Record Group 40, Records of the Department of Commerce (College Park, MD). General Records of the Department of Commerce, Office of the Secretary, General Correspondence.

15 "Senate Unit Raises New Census Issue," New York Times, March 21, 1940, p. 17. Austin had worked for the bureau since the turn of the century and was aware of the confidentiality breaches during World War I and the early 1920s. Cf. Barabba: "personal information for several hundred young men was released to courts, draft boards, and the Justice Department." We understand Austin's public statement to be technically correct. What he did not say was that the "law" requiring secrecy was 11 years on the books, not 150, as he implied. Austin personally was very committed to statistical confidentiality and worked hard to guarantee it. See Anderson and Seltzer 2007. 
Record Group 51, Division of Statistical Standards, Records of the Office of Management and Budget (College Park, MD).

General Records, 1940-1968, Entries 147; 147B; and Series 39.1, General Legislation, 76th - 79th Cong. 1939-1946.

Tom C. Clark Papers, Box A124, Folder 47, Rare Books \& Special Collections, Tarlton Law Library, The University of Texas at Austin.

Stuart A. Rice Papers, Harry S. Truman Presidential Library, Independence, MO.

Henry Morgenthau Jr. Papers, Franklin Delano Roosevelt Presidential Library, Hyde Park, NY

Support for this research has come from Institute for Race and Ethnicity at the University of Wisconsin Milwaukee, the Harry Truman Presidential Library, and the Institute for Research in the Humanities at UW-Madison. An earlier version of this paper was delivered at the 2005 meeting of the Federal Committee on Statistical Methodology in Arlington, VA. In addition, the present paper incorporates recent research findings related to disclosures of business data by the U.S. Census Bureau in the 1942-1947 period under the Second War Powers Act and presented in Seltzer and Anderson (2007a). 


\section{References}

Anderson, M. (1988), The American Census: A Social History, New Haven: Yale University Press, 1988.

Anderson M. and Seltzer, W. (2007), "Challenges to the Confidentiality of U.S. Federal Statistics, 1910-1965," Journal of Official Statistics, 23, 1, 1-34.

Ankeny, M. (1957a), Letter to Fred Seaton, March 8, 1957, Folder: Release and Publication of Statistical Information...; Box 100: Release and Publication of Statistical Information...; Entry 147, General Records, 1940-1968; RG 51, Records of the Office of Management and Budget, NARA.

Ankeny, M. (1957b), Memorandum to Solicitor, August 19, 1957, Folder: Release and Publication of Statistical Information....; Box 100: Release and Publication of Statistical Information...; Entry 147, General Records, 1940-1968; RG 51, Records of the Office of Management and Budget, NARA.

Ankeny, M. (1958), Memorandum to Assistant Secretary, Mineral Resources, April 18, 1958 in Folder: Release and Publication of Statistical Information....; Box 100: Release and Publication of Statistical Information...; Entry 147, General Records, 1940-1968; RG 51, Records of the Office of Management and Budget, NARA.

Barabba, V. (1975), "The Right of Privacy and the Need to Know," in U.S. Census Bureau, The Census Bureau: A Numerator and Denominator for Measuring Change, Technical Paper 37. Washington, D.C.: Government Printing Office.

Bohme, F. G., and Pemberton, D.N. (1991), "Privacy and Confidentiality in the US Censuses - A History." Paper presented at the annual meeting of the American Statistical Association. Atlanta, GA, August 18-22.

Bowman, R. (1958) Memorandum to Secretary of the Interior; Memorandum to Attorney General, August 27, 1958, Folder: Release and Publication of Statistical Information....; Box 100: Release and Publication of Statistical Information...; Entry 147, General Records, 19401968; RG 51, Records of the Office of Management and Budget, NARA.

Brownell, H. (1957a), Letter to Fred Seaton, February 19, 1957, Folder: Release and Publication of Statistical Information...; Box 100: Release and Publication of Statistical Information...; Entry 147, General Records, 1940-1968; RG 51, Records of the Office of Management and Budget, NARA.

Brownell, H. (1957b), Letter to Fred Seaton, August 7, 1957, Folder: Release and Publication of Statistical Information...; Box 100: Release and Publication of Statistical Information...; Entry 147, General Records, 1940-1968; RG 51, Records of the Office of Management and Budget, NARA.

Chilson H. (1957), Letter to Herbert Brownell, September 5, 1957, Folder: Release and Publication of Statistical Information...; Box 100: Release and Publication of Statistical Informa- 
tion...; Entry 147, General Records, 1940-1968; RG 51, Records of the Office of Management and Budget, NARA.

Clark, T. (1961), Memorandum to the Conference, November 15, 1961, Tom C. Clark Papers, Box A124, Folder 47, Rare Books \& Special Collections, Tarlton Law Library, The University of Texas at Austin.

Clemence, T. (1986), Letter from Theodore G. Clemence, Senior Advisor, to Annelise Anderson, Hoover Institution, 8/20/1986. NARA, RG 29, Administrative Records of the Bureau of the Census, Entry 372L Files of C. Louis Kincannon, Deputy Director (1981-1992), Alphabetic Files (Advisory Committee - Voting Rights), Box 24, Integrated Survey Proc. to Legislation, Folder "Japanese Americans."

Congressional Record (1941), (77th Cong., 1st Session), volume 87, pt. 6, 6969, August 11.

Corcoran, T. F. (1963), "On the Confidential Status of Census Reports" The American Statistician. 17, 3, 33-40.

Dandeker, C. (1990), Surveillance, Power and Modernity: Bureaucracy and Discipline from 1700 to the Present Day, Cambridge, UK: Polity Press.

Daniels, R. (1982), "The Bureau of the Census and Relocation of the Japanese Americans: A Note and a Document." Amerasia Journal 9: 101-105.

Duncan, G., Jabine, T.B.. and de Wolf, V.A., eds. (1993), Private Lives and Public Policies: Confidentiality and Access of Government Statistics. Panel on Confidentiality and Data Access, Committee on National Statistics, National Research Council and the Social Science Research Council. Washington, D.C.: National Academy Press.

Duncan, J. W. (1976), "Confidentiality and the Future of the U.S. Statistical System." The American Statistician. 30, 2, 54-59.

Duncan, J. W., and Shelton, W.C. (1978), Revolution in United s Government Statistics, 19261976. Washington, D.C.: Government Printing Office.

Eaton, M (1948), Interoffice note to the Solicitor, Commerce Department, July 9, 1948, Office of the Secretary, General Correspondence, 67001 (Part 3 to Part 7), Box 94, File 67001 (part 3 of 7), RG40, General Records of the Department of Commerce, NARA.

Eckler, A. R. (1972), The Bureau of the Census. New York: Praeger.

Engler, R. (1961), The Politics of Oil: Private Power and Democratic Directions. Chicago: University of Chicago Press.

Federal Trade Commission v. Dilger (1960), 276 F.2d 739.

Fleming, B.A. (1942) Letter to Harold Smith, November 4, 1942, File R84, Reporting Services, Coordinate, Box 154, Series 391, General Legislation, 76th - 79th Cong. 1939-1946; Record 
Group 51, Records of the Office of Management and Budget (Bureau of the Budget), NARA.

Foster, W.C. 1947. Letter from the Acting Secretary of Commerce to the Attorney General, December 12, 1947, Office of the Secretary, General Correspondence, 67104 (Part 2) - 67104 (Part 5), Box 144, File 67104 (Part 5), RG40, General Records of the Department of Commerce, NARA.

. 1948a. Letter from the Acting Secretary of Commerce to the Attorney General, May / 27, 1948, ,, Office of the Secretary, General Correspondence, 67104-67105, Box 146, File 67104, RG40, General Records of the Department of Commerce, NARA.

1948b. Memorandum from the Under Secretary of Commerce to J. C. Capt, Director Census Bureau, "Securing Consent of Individuals and Firms Supplying Information Pursuant to the Manufactures' Census Desired by the Munitions Board and Other Interested Government Agencies," May 27, 1948, Office of the Secretary, General Correspondence, 67104-67105, Box 146, File 67104, RG40, General Records of the Department of Commerce, NARA.

Frankel, P. H. (1959), "Oil Supplies During the Suez Crisis - On Meeting a Political Emergency," The Journal of Industrial Economics. 6, 2 , 85-100.

Goldberg, J. P., and Moye W.T. (1985), The First Hundred Years of the Bureau of Labor Statistics. Washington, D.C.: Government Printing Office.

Goldfield, E. D. (1991), Oral History Interview, October 8, 1991 with interviewer Frederick G. Bohme, Chief, History Staff at the Census Bureau, http://www. census.gov/prod/2003pubs/OH-GOLDF.PDF

Hayter, H. H. (1892), General Report of the Census of Victoria, 1891. Melbourne: Robert S. Brain, Government Printer.

Headrick, D. (2000), When Information Came of Age: Technologies of Knowledge in the Age of Reason and Revolution, 1700-1850. New York: Oxford University Press.

Higgs, E. (2004), The Information State in England, The Central Collection of Information on Citizens since 1500. StateNew York: Palgrave Macmillan.

Howrey, E.F. (1953), Letter to Ralph Watkins, October 27, 1953, "Suggestions for Improving the Utility of Bureau of the Census Data," File: Census: Intensive Review Committee Folder \# 1; Box 58, Entry 147, Census - Census (Intensive Review Committee); Record Group 51, Records of the Office of Management and Budget, General Records, 1940-1968, NARA

Intensive Review Committee to the Secretary of Commerce (1953), "Appraisal of Census Programs: Report of the Intensive Review Committee to the Secretary of Commerce," File: Watkins Intensive Review Committee, Box 58, Entry 147, Census: Intensive Review Committee; Record Group 51, Records of the Office of Management and Budget, General Records, 1940-1968; NARA.

Jones, C. D. (2005). "The Role of Population Statistics and the Japanese War Relocation Program," Unpublished paper, US Census Bureau. Copy provided by author. 
Kaufman, B. I. (1977), "Mideast Multinational Oil, U.S. Foreign Policy, and Antitrust: the 1950s," Journal of American History, 63, 4, 937-959.

Kerlin, Malcolm. 1942. Routing slip from the Administrative Assistant to the Secretary of Commerce to Mr. Capt, "Donald M. Nelson (req. for confidential data)," 8/18/1942. NARA, RG40, General Records of the Department of Commerce, General Correspondence, 102517, Box 951, File 102517 (Part 3 of 7).

Kovaleff, T. P. (1980), Business and Government During the Eisenhower Administration. Athens: The Ohio State University Press.

Lewis, A. (1958), "U.S. Jury Indicts 29 Oil Concerns as Price Fixers," New York Times, May 30, p. 1 .

Linnenberg C. (1945), Letter to Stuart A. Rice, April 30, 1945, "Legal Right of Department of Justice to Obtain Individual-Company Information from Other Agencies," File: Privacy; Box 105, Entry 147B, Record Group 51, Division of Statistical Standards, General Records, 1940-1968, Restricted Material, NARA.

Lyon, D. (2001), Surveillance Society: Monitoring Everyday Life. Philadelphia: Open University Press.

Morgenthau, H. Jr. (1943). Letter from the Treasury Secretary to Jesse Jones, March 16, 1943. FDR Library, Henry Morgenthau Jr. Papers, Correspondence 1933-1945, War Savings(1942July 1943) Box 307, Folder "March-July 1943.

Okamura, R. Y. (1981), "The myth of census confidentiality." Amerasia Journal, 8 111-120.

Parenti, C. (2004), The Soft Cage: Surveillance in America from Slavery to the War on Terror. New York: Basic Books.

President's Commission on Federal Statistics. (1971), Federal Statistics: Report of the President's Commission (2 volumes). Washington, D.C.: Government Printing Office.

Rice, S. A. (1942a). Letter from the Assistant Director in Charge of Statistical Standards to Stacy May, Chief Statistical Division, War Production Board. 8/14/1942 and attached list. Harry S. Truman Library, Rice papers, Box 3, Government File 1933-1950, Chronological File, 1/41-6/43, July-December 1942.

(1942b). Letter from the Assistant Director in Charge of Statistical Standards to Oscar B. Ryder, Vice Chairman, United States Tariff Commission, 8/14/1942. Harry S. Truman Library, Rice papers, Box 3, Government File 1933-1950, Chronological File, 1/41-6/43, JulyDecember 1942.

. (1942c). Letter from the Assistant Director in Charge of Statistical Standards to H. F. Taggart, Dirctor, Accounting Division, Office of Price Administration, 8/14/1942. Harry S. Truman Library, Rice papers, Box 3, Government File 1933-1950, Chronological File, 1/416/43, July-December 1942. 
Rubin, E. (1962), "Questions and Answers: Government Statistics and Confidentiality of Response." The American Statistician. 16, 4, 27-30.

Sawyer, C. (1948), Letter from Secretary of Commerce to the Commissioner, Bureau of Internal Revenue, July 15, 1948, Office of the Secretary, General Correspondence, 67001 (Part 3 to Part 7), Box 94, File 67001 (part 3 of 7), RG40, General Records of the Department of Commerce, NARA.

Scammon R. (1961), Letter to Lee Lovinger, June 19, 1961, Folder: Release and Publication of Statistical Information....Commerce Department, Census Bureau; Box 101, Release and Publication of Statistical Information....Public Access, Entry 147, General Records, 1940-1968, RG 51, Records of the Office of Management and Budget, NARA.

Seltzer, W. and Anderson, M. (2001), "The Dark Side of Numbers: The Role of Population Data Systems in Human Rights Abuses," Social Research, 68, 2, 481-513.

(2002), "NCES and the Patriot Act: An Early Appraisal of Facts and Issues." Paper prepared for presentation at the annual Joint Statistical Meetings, New York, August 10-15, 2002 .

(2007a), "Census Confidentiality under the Second War Powers Act (1942-1947)." Paper prepared for presentation at the annual meeting of the Population Association of America, New York, March 29-31, 2007.

(2007b), "Using Population Data Systems to Target vulnerable Population Subgroups and Individuals: Issues and Incidents." In Statistical Methods for Human Rights, Asher, J., Banks, D., and Scheuren, F. J. (eds.), Berlin: Springer-Verlag, Chapter 13. Originally presented as "Government Statistics and Individual Safety: Revisiting the Historical Record of Disclosure, Harm, and Risk," at a workshop, Access to Research Data: Assessing Risks and Opportunities, organized by the Panel on Confidential Data Access for Research Purposes, Committee on National Statistics (CNSTAT), Washington (October 16-17, 2003).

Smith H. (1942), Letter to Bruce A. Fleming, November 17, 1942, File R84, Reporting Services, Coordinate, Box 154, Series 39.1, General Legislation, 76th - 79th Cong. 1939-1946; Record Group 51, Records of the Office of Management and Budget (Bureau of the Budget), NARA.

St. Regis Paper Company vs the United States. (1961), 368 US 208.

Staats E, (1958), Memorandum to Peyton Stapp, December 2, 1958, Folder: Release and Publication of Statistical Information....; Box 100: Release and Publication of Statistical Information...; Entry 147, General Records, 1940-1968; RG 51, Records of the Office of Management and Budget, NARA.

Stapp, P. (1958a), Memorandum to Elmer Staats, November 28, 1959, Folder: Release and Publication of Statistical Information....; Box 100: Release and Publication of Statistical Information...; Entry 147, General Records, 1940-1968; RG 51, Records of the Office of Management and Budget, NARA. 
Stapp, P. (1958b), Memorandum to file, December 2, 1959, Folder: Release and Publication of Statistical Information....; Box 100: Release and Publication of Statistical Information...; Entry 147, General Records, 1940-1968; RG 51, Records of the Office of Management and Budget, NARA.

Steuart, W.M. (1922), Letter to Walter Willcox, March 27, 1922, RG 29, Entry 202, Hill Papers, Box 226.

Taylor, Wayne C. 1942. Letter from the Acting Secretary of Commerce to the Chairman, War Production Board, 8/21/1942. NARA, RG40, General Records of the Department of Commerce, General Correspondence, 102517, Box 951, File 102517 (Part 3 of 7).

- 1943a. Letter from the Under Secretary of Commerce to Grover B. Hill, Assistant Secretary, Department of Agriculture, 2/4/1944. NARA, RG40, General Records of the Department of Commerce, Office of the Secretary, General Correspondence, 67104 (Part 2) 67104 (Part 5), Box 144, File 67104 (Part 3).

1943b. Letter from the Under Secretary of Commerce to Eugene W. Sloan, Executive Director, War Savings Staff, Treasury Department, 2/27/1943. NARA, RG40, General Records of the Department of Commerce, Office of the Secretary, General Correspondence, 67104 (Part 2) - 67104 (Part 5), Box 144, File 67104 (Part 3).

1943c. Letter from the Under Secretary of Commerce to Charles B. Lawrence Jr., Director, Statistical Standards Office, Office of Price Administration, 2/27/1943. NARA, RG40, General Records of the Department of Commerce, Office of the Secretary, General Correspondence, 67104 (Part 2) - 67104 (Part 5), Box 144, File 67104 (Part 3).

- . 1943d.. Letter from the Acting Secretary of Commerce to the Secretary of Treasury, 3/18/1943. NARA, RG40, General Records of the Department of Commerce, Office of the Secretary, General Correspondence, 67104 (Part 2) - 67104 (Part 5), Box 144, File 67104 (Part $3)$.

. 1944a. Letter from the Under Secretary of Commerce to Stuart A. Rice, Assistant Director, Bureau of the Budget, 4/15/1944. NARA, RG40, General Records of the Department of Commerce, Office of the Secretary, General Correspondence, 67104 (Part 2) - 67104 (Part 5), Box 144, File 67104 (Part 3).

1944b. Letter from the Under Secretary of Commerce to J. C. Capt, Director, Census Bureau, 4/15/1944. NARA, RG40, General Records of the Department of Commerce, Office of the Secretary, General Correspondence, 67104 (Part 2) - 67104 (Part 5), Box 144, File 67104 (Part 3).

U.S. Census Bureau (1917), Legislation Relating to the Bureau of the Census, July 1, 1917, Census of Population and Housing, Special Collections, http://www2.census.gov/prod2/decennial/documents/12016444_toc.pdf

U.S. Census Bureau, (2004), "Census Confidentiality and Privacy: 1790 - 2002," http://www. census.gov/prod/2003pubs/conmono2.pdf (accessed 6/26/2007). 
U.S. Code Congressional Service. (1943), Acts of 7rth Congress. St. Paul, MN: West Publishing Company.

U.S. General Accounting Office. Energy Security and Policy: Analysis of the Pricing of Crude Oil and Petroleum Products. 1993 Report GAO/RCED-93-17. Washington, D.C.: Government Printing Office, 1993.

U.S. House of Representatives, Committee on Post Office and Civil Service. (1962), Confidentiality of Census Reports. Hearings before the Committee on Post Office and Civil Service, House of Representatives (87th Congress, 2d Session), July 31 and August 1, 1962. Washington, D.C.: Government Printing Office.

U. S. House of Representatives, Committee on the Census. (1941), Quinquennial Census of Industry and Business, Hearings before the Committee on the Census, House of Representatives (77th Congress, 1st Session), October 14, 15, 16, 21, 22, 23, 28, 29, and November 6, 1941. Washington, D.C: Government Printing Office.

U.S. Office of Management and Budget (2007), "Implementation Guidance for Title V of the E-Government Act, Confidential Information Protection and Statistical Efficience Act of 2002 (CIPSEA)," Federal Register, 72, No. 115, 33362-77, June 15, 2007.

U. S. Senate. (1957), "Emergency Oil Life Program and Related Oil Problems." Joint Hearings Before Subcommittees of the Committee on the Judiciary and Committee on Interior and Insular Affairs, 85th Cong., 1st Sess. Washington, D.C.: Government Printing Office.

Wallace, H. A. (1945a),. Letter from Secretary of Commerce to David E. Lilienthal, Chairman, Tennessee Valley Authority, 3/9/1945. NARA, RG40, General Records of the Department of Commerce, Office of the Secretary, General Correspondence, 104262-104279, Box 1078, File 104262-104276.

. (1945b), Letter from Secretary of Commerce to the Secretary of Agriculture, 4/5/1945. NARA, RG40, General Records of the Department of Commerce, Office of the Secretary, General Correspondence, 67104 (Part 2) - 67104 (Part 5), Box 144, File 67104 (Part 3).

- (1945c), Letter from Secretary of Commerce to David E. Lilienthal, Chairman, Tennessee Valley Authority, 4/7/1945. NARA, RG40, General Records of the Department of Commerce, Office of the Secretary, General Correspondence, 104262-104279, Box 1078, File 104262-104276.

(1945d), Letter from Secretary of Commerce to L. B. Schwellenbach, Secretary of Labor, 8/2/1945. NARA, RG40, General Records of the Department of Commerce, Office of the Secretary, General Correspondence, 67104 (Part 2) - 67104 (Part 5), Box 144, File 67104 (Part 3).

(1945e), Letter from Secretary of Commerce to John D. Small, Chairman, Civilian Production Administration, 11/29/1945. NARA, RG40, General Records of the Department of Commerce, Office of the Secretary, General Correspondence, 102517/106-108, Box 973, File $102517 / 106$. 
Wallman, K. K. (2003), "Data Access and Confidentiality - the Changing Legal Landscape." Discussion prepared for presentation at a workshop, Access to Research Data: Assessing Risks and Opportunities, organized by the Panel on Confidential Data Access for Research Purposes, Committee on National Statistics (CNSTAT), The National Academies, Washington, D.C., October 16-17, 2003.

Available at http://www7.nationalacademies.org/cnstat/Katherine_Wallman.pdf

Warren E. (1961), Memorandum to Tom C. Clark, November 16,1961, in Tom C. Clark Papers, Box A124, Folder 47, Rare Books \& Special Collections, Tarlton Law Library, The University of Texas at Austin.

Willcox, W. (1914), "The Development of the American Census Office since 1890." Political Science Quarterly. 29, 3, 438-59. 


\begin{tabular}{|c|c|c|c|c|}
\hline \multirow{2}{*}{\multicolumn{5}{|c|}{$\begin{array}{c}\text { Table A - Summary of Section } 1402 \text { Business-related Disclosures } \\
\text { (Disclosures identified through June 2006) }\end{array}$}} \\
\hline & & & & \\
\hline $\begin{array}{l}\text { Requesting } \\
\text { agency }\end{array}$ & $\begin{array}{l}\text { Material requested } \\
\text { or provided }\end{array}$ & Purpose & $\begin{array}{l}\text { Date of } \\
\text { request }\end{array}$ & Documentation of response(s) \\
\hline $\begin{array}{l}\text { War Production } \\
\text { Board }\end{array}$ & $\begin{array}{l}\text { Confidential industrial } \\
\text { and economic informa- } \\
\text { tion }\end{array}$ & NA & $8 / 17 / 42$ & $\begin{array}{l}\text { Letter Wayne C. Taylor, Acting Sec- } \\
\text { retary of Commerce to Donald M. } \\
\text { Nelson, Chairman, War Production } \\
\text { Board, } 8 / 21 / 1942 \text {, NARA, RG40 }\end{array}$ \\
\hline $\begin{array}{l}\text { Department of } \\
\text { Agriculture, } \\
\text { Food Distribu- } \\
\text { tion Agency }\end{array}$ & $\begin{array}{l}\text { Confidential mailing } \\
\text { lists }\end{array}$ & NA & $2 / 4 / 43$ & $\begin{array}{l}\text { Letter Wayne C. Taylor, Undersecre- } \\
\text { tary of Commerce to Grover B. Hill, } \\
\text { Assistant Secretary, Dept. of Agricul- } \\
\text { ture, NARA, RG40 }\end{array}$ \\
\hline $\begin{array}{l}\text { Office of Price } \\
\text { Administration }\end{array}$ & $\begin{array}{l}\text { Mailing lists from the } \\
1939 \text { Retail Census }\end{array}$ & NA & $2 / 27 / 43$ & $\begin{array}{l}\text { Letter Taylor to Charles B. Lawrence, } \\
\text { Jr. Director of Statistical Standards } \\
\text { Office, OPA, NARA, RG40 }\end{array}$ \\
\hline $\begin{array}{l}\text { Treasury } \quad \text { De- } \\
\text { partment }\end{array}$ & $\begin{array}{l}\text { Confidential mailing } \\
\text { lists to be compiled } \\
\text { from the retail census } \\
\text { records }\end{array}$ & $\begin{array}{l}\text { War Sav- } \\
\text { ings drive }\end{array}$ & $3 / 18 / 43$ & $\begin{array}{l}\text { Letter Taylor to Henry Morgenthau } \\
\text { Jr., Treasury Secretary, NARA, RG40 }\end{array}$ \\
\hline $\begin{array}{l}\text { Defense Plants } \\
\text { Corporation }\end{array}$ & $\begin{array}{l}\text { Production of specified } \\
\text { chemical products, by } \\
\text { individual plants, from } \\
\text { the } 1939 \text { Biennial Cen- } \\
\text { sus and latest monthly } \\
\text { production }\end{array}$ & NA & $4 / 15 / 44$ & $\begin{array}{l}\text { Letter Taylor to Capt, NARA, RG40. } \\
\text { See also letter from Taylor to Rice, } \\
\text { 4/15/44, forwarding him a copy of the } \\
\text { letter to Capt }\end{array}$ \\
\hline $\begin{array}{l}\text { Requesting } \\
\text { agency }\end{array}$ & $\begin{array}{l}\text { Material requested } \\
\text { or provided }\end{array}$ & Purpose & $\begin{array}{l}\text { Date of } \\
\text { request }\end{array}$ & Documentation of response(s) \\
\hline $\begin{array}{l}\text { Tennessee Valley } \\
\text { Authority }\end{array}$ & $\begin{array}{l}\text { Confidential census in- } \\
\text { formation on the pro- } \\
\text { duction of superphos- } \\
\text { phate }\end{array}$ & NA & $3 / 9 / 45$ & $\begin{array}{l}\text { Letter from Henry A. Wallace, Secre- } \\
\text { tary of Commerce, to David E. Lilien- } \\
\text { thal, Chairman, TVA, NARA, RG40 }\end{array}$ \\
\hline $\begin{array}{l}\text { Department } \\
\text { of Agricul- } \\
\text { ture, Bureau } \\
\text { of Agricultural } \\
\text { Economics }\end{array}$ & $\begin{array}{l}\text { Lists of large farms, } \\
\text { names and addresses of } \\
\text { various farm operators, } \\
\text { and other information } \\
\text { from the } 1945 \text { Census } \\
\text { of Agriculture }\end{array}$ & NA & $4 / 5 / 45$ & $\begin{array}{l}\text { Letter Wallace to Secretary of Agri- } \\
\text { culture, NARA, RG40 }\end{array}$ \\
\hline $\begin{array}{l}\text { Department of } \\
\text { Labor }\end{array}$ & $\begin{array}{l}\text { List of all } 1939 \\
\text { manufacturing } \\
\text { lishments }\end{array}$ & $\begin{array}{l}\text { Work of } \\
\text { the BLS }\end{array}$ & $8 / 2 / 45$ & $\begin{array}{l}\text { Letter Wallace to Secretary of Labor, } \\
\text { NARA, RG40 }\end{array}$ \\
\hline $\begin{array}{l}\text { Civilian Produc- } \\
\text { tion Administra- } \\
\text { tion }\end{array}$ & $\begin{array}{l}\text { Confidential data from } \\
\text { the } 1939 \text { Census of } \\
\text { Manufactures }\end{array}$ & NA & $11 / 29 / 45$ & $\begin{array}{l}\text { Letter Wallace to Chairman, Civil- } \\
\text { ian Production Administration to the } \\
\text { successor agency to the War Pro- } \\
\text { duction Board, proposing new tran- } \\
\text { sitional arrangements for the contin- } \\
\text { ued provision of confidential informa- } \\
\text { tion from the Census Bureau, NARA, } \\
\text { RG40 }\end{array}$ \\
\hline
\end{tabular}

